\title{
Metal bioavailability in the Sava River water
}

*Zrinka Dragun ${ }^{1}$, Vlatka Filipović Marijić ${ }^{1}$, Marijana Vuković ${ }^{2}$ and Biserka Raspor $^{1}$

${ }^{1}$ Ruđer Bošković Institute, Division for Marine and Environmental Research, Laboratory for Biological Effects of Metals, P.O. Box 180, 10002 Zagreb, Croatia

${ }^{2}$ Zeleni servis d.o.o., Templarska 23, 21000 Split, Croatia

* Corresponding author

$\begin{array}{lr}\text { Phone: } & \text { xx385-1-4680216; } \\ \text { Fax: } & \text { xx385-1-4680242; } \\ \text { E-mail: } & \text { zdragun@irb.hr }\end{array}$

\begin{abstract}
Metals present one of the major contamination problems for freshwater systems, such as the Sava River, due to their high toxicity, persistence, and tendency to accumulate in sediment and living organisms. The comprehensive assessment of the metal bioavailability in the Sava River encompassed the analyses of dissolved and DGT-labile metal species of nine metals ( $\mathrm{Cd}, \mathrm{Co}, \mathrm{Cr}, \mathrm{Cu}, \mathrm{Fe}, \mathrm{Mn}, \mathrm{Ni}, \mathrm{Pb}$, and $\mathrm{Zn}$ ) in the river water, as well as evaluation of accumulation of five metals $(\mathrm{Cd}, \mathrm{Cu}, \mathrm{Fe}$, $\mathrm{Mn}$, and $\mathrm{Zn}$ ) in three organs (liver, gills and gastrointestinal tissue) of bioindicator organism, fish species European chub (Squalius cephalus L.). This survey was conducted mainly during the year 2006, in two sampling campaigns, in April/May and September, as periods representative for chub spawning and postspawning. Additionally, metal concentrations were determined in the intestinal parasites acanthocephalans, which are known for their high affinity for metal accumulation. Metallothionein concentrations were also determined in three chub organs, as a commonly applied biomarker of metal exposure. Based on the metal concentrations in the river water, the Sava River was defined as weakly contaminated and mainly comparable with unpolluted rivers, which enabled the analyses of physiological variability of metal and metallothionein concentrations in the chub organs, as well as establishment of their constitutive levels.
\end{abstract}




\section{Introduction}

In the aquatic environment, metals present one of the major contamination problems and a permanent threat to health of both aquatic organisms and eventually humans, due to their high toxicity, persistence, and tendency to accumulate in sediment and living organisms (Has-Schön et al. 2006). Metals in aquatic ecosystem originate from natural and anthropogenic sources, such as industrial and domestic runoff, agricultural sources, mining, natural leaching, and geological weathering. Some metals, like $\mathrm{Zn}, \mathrm{Cu}, \mathrm{Fe}$, and $\mathrm{Mn}$, are required by aquatic organisms for their normal growth and physiological functions. For the majority of animal species, the uptake of these metals occurs from a combination of water and food, including sediment (Langston and Spence 1995). However, together with essential metals, toxic metals, like $\mathrm{Cd}, \mathrm{Hg}, \mathrm{Ag}$, for which no clear biological function was established, are also accumulated from surrounding media (Foulkes 2000). Therefore, for comprehensive assessment of aquatic systems contamination with metals, the information on their levels in both water and aquatic organisms is needed.

Among freshwater organisms, fish are often used in the environmental biomonitoring due to their role in the biotic communities and their sensitivity to low concentrations of environmental pollutants (Olsson et al. 1998). Metals are taken up by fish through skin, gills and gastrointestinal tract, and therefore, common indicator organs for the assessment of metal bioavailability in the river water are gills and gastrointestinal tissue, as metal uptake organs and liver and kidney, as metal detoxification organs. Specific and direct response to elevated intracellular metal concentrations is the induction of the synthesis of metalothioneins (MT), a family of low-molecular, cysteine-rich proteins, known as biomarkers of metal exposure (Olsson et al. 1998).

Metal exposure assessment of the Sava River involved evaluation of the dissolved and labile metal concentrations in the river water, as well as cytosolic concentrations of metals and MTs in three organs (liver, gills and gastrointestinal tissue) of European chub (Squalius cephalus L.), which was selected as the representative indicator species among fish communities inhabiting the Sava River. Metal concentrations in the chub intestinal parasites, acanthocephalans, were additionally assessed. Acanthocephalans are potentially sensitive biological indicators which accumulate metals more effectively than their host organisms - the fishes (Sures 2003). 


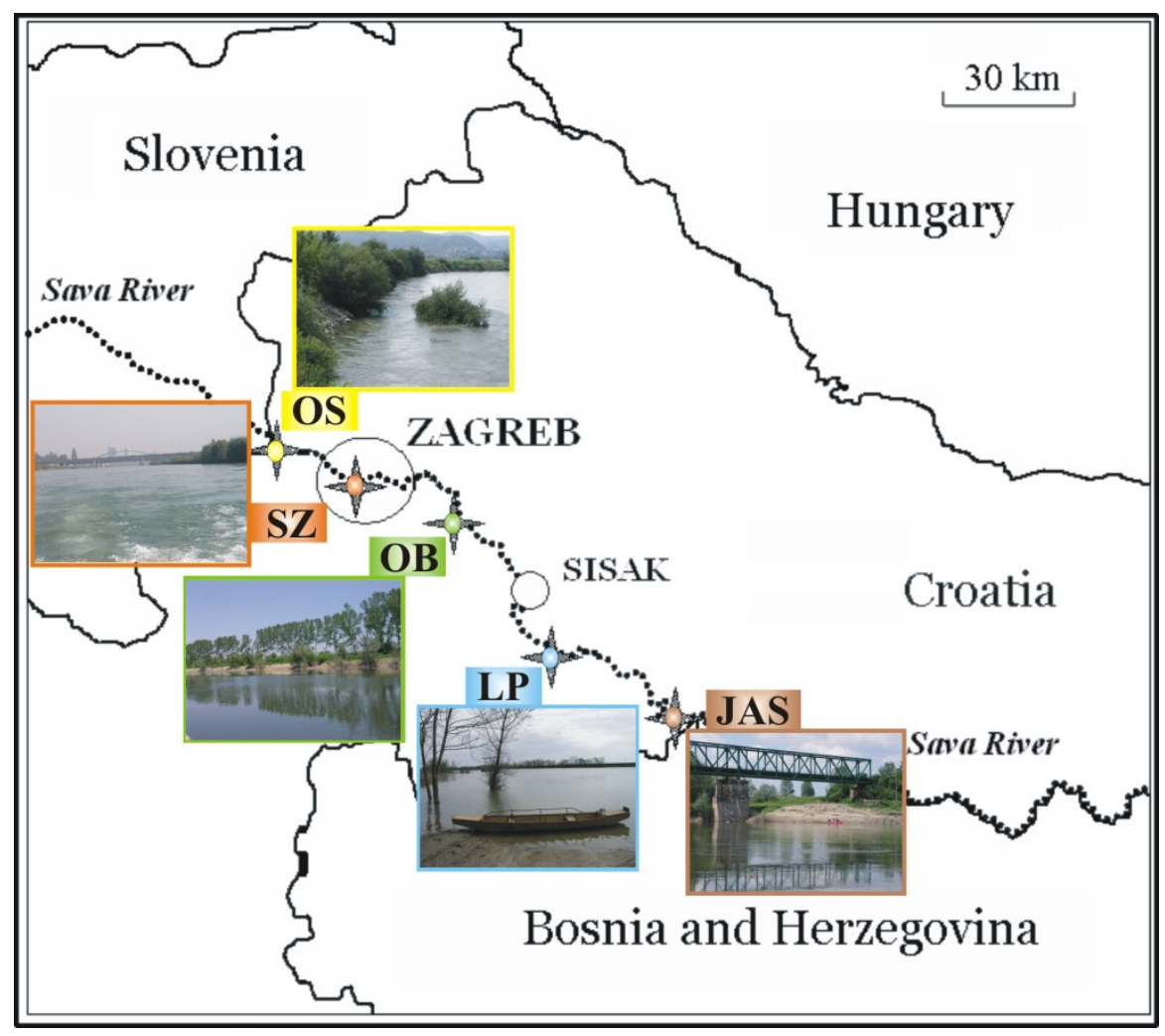

Figure 1. The map of $150 \mathrm{~km}$ long sampling section of the Sava River in Croatia, with marked sampling sites (OS- Otok Samoborski, SZ - Sava in Zagreb, OBOborovo, LP- Lukavec Posavski, JAS- Jasenovac).

The samplings were conducted at $150 \mathrm{~km}$ long section of the Sava River in Croatia, starting at the Croatian-Slovenian state border (Otok Samoborski) and ending at the state border between Croatia and Bosnia and Herzegovina (Jasenovac). The following 5 sampling sites were selected (Fig. 1):

1. Otok Samoborski - low-polluted reference location (10 km upstream of Zagreb);

2. Zagreb - located within the Zagreb city area, but $20 \mathrm{~km}$ upstream of the main household and industrial wastewater outlets;

3. Oborovo (Fig. 2) - located $15 \mathrm{~km}$ downstream of the industrial and municipal effluents of Zagreb (1 million inhabitants and heavily industrialized) and $5 \mathrm{~km}$ downstream of the wastewater outlet of the city of Velika Gorica (35,000 inhabitants);

4. Lukavec Posavski - $15 \mathrm{~km}$ downstream of the Sisak city $(55,000$ inhabitants, oil refinery, pesticide production facility, ironworks); 
5. Jasenovac $-50 \mathrm{~km}$ downstream of the Sisak city, close to the confluence of the Una River (the Sava River right tributary) (Krča et al. 2007).

Geographic coordinates and basic physico-chemical parameters of the selected locations are shown in Table 1 (Dragun et al. 2009a). Two sampling campaigns were performed during 2006, in April/May, coinciding with the chub spawning and presumably higher water filtration through gills, as well as more intense feeding, and in September, coinciding with the chub post-spawning period and presumably lower metabolic activity.

Table 1. Fish sampling sites, the coordinates recorded with GPSMAP 76CS (Garmin International, USA), and basic physico-chemical parameters of the Sava River water in April/May and September of 2006.

\begin{tabular}{|c|c|c|c|c|c|c|c|c|}
\hline \multirow{2}{*}{$\begin{array}{c}\text { Fish } \\
\text { sampling } \\
\text { sites }\end{array}$} & \multicolumn{4}{|c|}{ April/May, 2006} & \multicolumn{4}{|c|}{ September, 2006} \\
\hline & ${ }^{\mathrm{a}} \mathbf{W T}$ & pH & ${ }^{\mathrm{b}} \mathbf{O}_{2}$ & 'Con. & ${ }^{\mathrm{a}} \mathbf{W T}$ & pH & ${ }^{\mathrm{b}} \mathbf{O}_{2}$ & ${ }^{\mathrm{c} C o n}$. \\
\hline $\begin{array}{c}\text { Otok } \\
\text { Samoborski } \\
\text { N } 45^{\circ} 50.543^{\prime} \\
\text { E } 15^{\circ} 43.497^{\prime}\end{array}$ & 12.8 & 7.87 & 97.9 & 465 & 18.4 & 8.26 & 82.1 & 433 \\
\hline $\begin{array}{c}\text { Sava in } \\
\text { Zagreb } \\
\text { N } 45^{\circ} 46.572^{\prime} \\
\text { E } 15^{\circ} 56.524^{\prime}\end{array}$ & 11.5 & 7.86 & 93.7 & 473 & 14.8 & 8.14 & 74.8 & 477 \\
\hline $\begin{array}{c}\text { *Oborovo } \\
\text { N } 45^{\circ} 41.286^{\prime} \\
\text { E } 16^{\circ} 14.875^{\prime}\end{array}$ & $\begin{array}{c}12.1 \\
-\end{array}$ & $\begin{array}{l}7.76 \\
7.82\end{array}$ & $\begin{array}{c}84.7 \\
-\end{array}$ & $\begin{array}{l}507 \\
486\end{array}$ & 16.1 & 7.81 & 62.4 & 408 \\
\hline $\begin{array}{c}\text { *Lukavec } \\
\text { Posavski } \\
\text { N } 45^{\circ} 24.081^{\prime} \\
\text { E } 16^{\circ} 32.337^{\prime}\end{array}$ & $\begin{array}{l}17.1 \\
11.7 \\
14.8\end{array}$ & $\begin{array}{l}7.85 \\
7.68 \\
7.59\end{array}$ & $\begin{array}{l}82.9 \\
80.5 \\
80.9\end{array}$ & $\begin{array}{l}491 \\
415 \\
495\end{array}$ & 16.7 & 7.78 & 63.5 & 395 \\
\hline $\begin{array}{c}\text { Jasenovac } \\
\text { N } 45^{\circ} 15.825^{\prime} \\
\text { E } 16^{\circ} 53.658^{\prime}\end{array}$ & 19.5 & 7.59 & 76.0 & 403 & 19.5 & 8.29 & 62.7 & 432 \\
\hline
\end{tabular}

* in the spring period, the chub sampling was performed at more than one occassion at two sites: two times at Oborovo and three times at Lukavec Posavski; the data are presented for each of these samplings separately;

${ }^{\mathrm{a}} \mathrm{WT}$ - water temperature $\left({ }^{\circ} \mathrm{C}\right)$;

${ }^{\mathrm{b}} \mathrm{O}_{2}$ - dissolved oxygen (\%);

${ }^{\mathrm{c}}$ Con. - water conductivity $\left(\mu \mathrm{S} \mathrm{cm}^{-1}\right)$ 


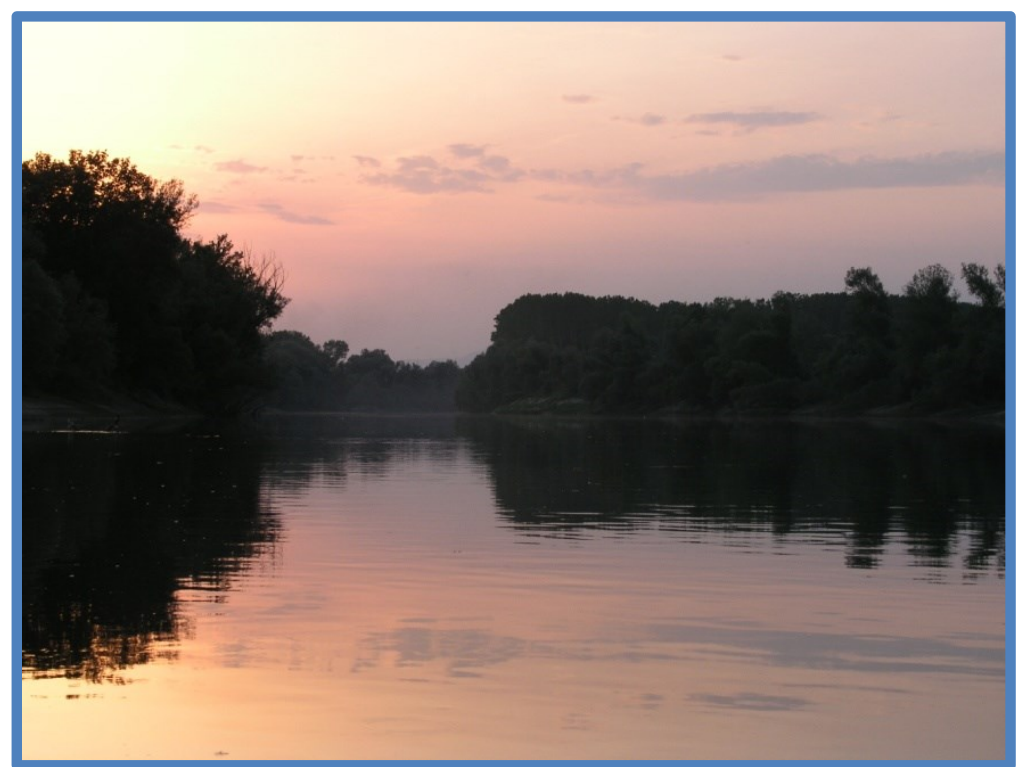

Figure 2. Sunset at the sampling site Oborovo in July, 2006.

\section{Dissolved metal concentrations in the Sava River water}

The metal fraction obtained after filtration of the river water through 0.45 $\mu \mathrm{m}$ filter is defined as dissolved metal fraction. It comprises free metal ions, as well as labile inorganic and organic complexes which could be easily introduced in the organs of aquatic organisms, and therefore are considered as bioavailable. However, the dissolved fraction is not regarded as fully bioavailable, since it also comprises inert high molecular organic metal complexes and colloids. Still, the measurement of dissolved metal fraction enables closer estimation of metal bioavailability in the water than determination of total metal concentrations which further comprise particulate metal fraction, collectable by $0.45 \mu \mathrm{m}$ filter (INAP 2002).

The concentrations of nine dissolved metals (Cd, Co, Cr, Cu, Fe, Mn, Ni, $\mathrm{Pb}$, and $\mathrm{Zn}$ ) in the Sava River water were determined during the spring of 2006. Several samplings (8-11, depending on the sampling site) were carried out in the period from March 28 to June 16 at three river sections under different anthropogenic impact: Zagreb, Oborovo, and Lukavec Posavski (Table 1). In the immediate vicinity of the sampling site Oborovo, i.e. $5 \mathrm{~km}$ upstream, a municipal sewage outlet of the city Velika Gorica effuses wastewater into the Sava River. To examine direct influence of the point source of pollution on the river water quality, two additional sampling points were selected in the Oborovo area: $0.5 \mathrm{~km}$ upstream

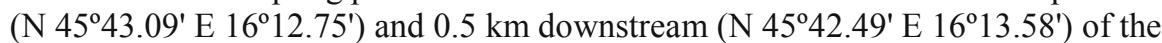
sewage outlet. The measurements were performed in the filtered and acidified $\left(0.65 \% \mathrm{HNO}_{3}\right.$, suprapur) samples of the river water using high resolution 
inductively coupled plasma-mass spectrometry (HR ICP-MS, Element 2, Thermo Finnigan, Germany) (Dragun et al. 2009c).
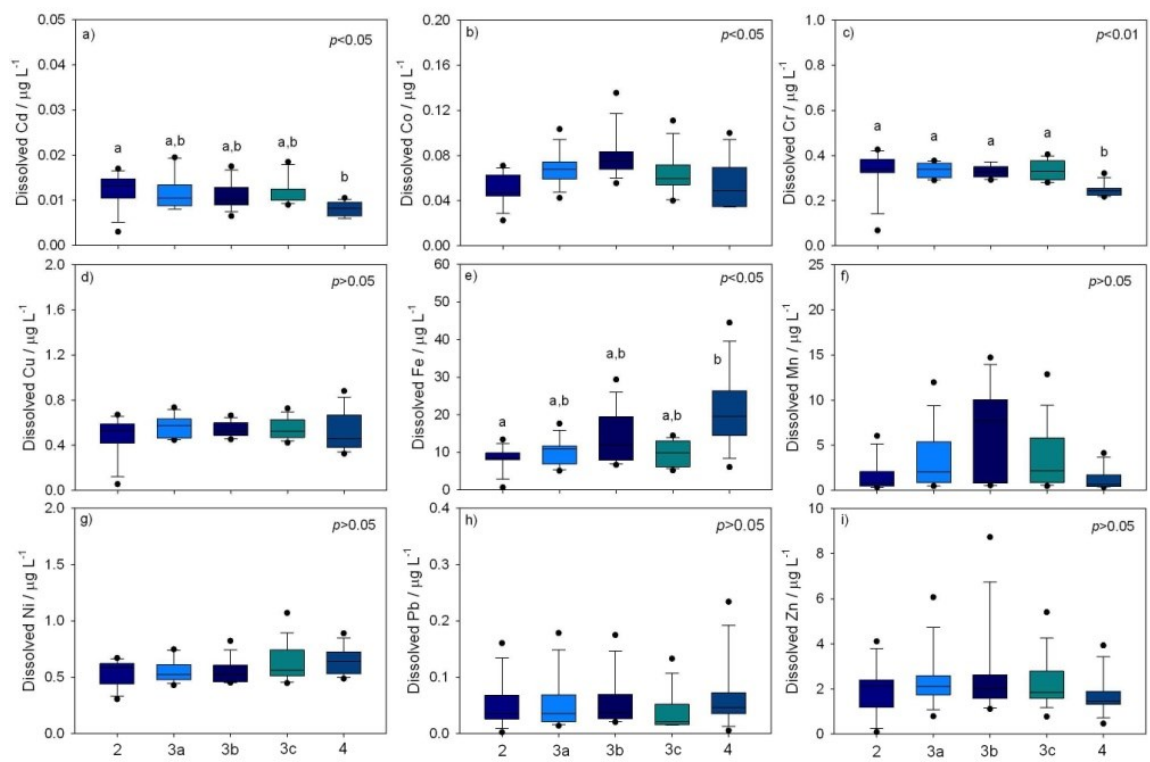

Figure 3. Spatial distribution of the concentrations of nine dissolved trace elements in the Sava River water, in the period from March 28 to June 16, 2006, at five sampling sites $(2-$ Zagreb $(\mathrm{n}=8) ; 3 \mathrm{a}-0.5 \mathrm{~km}$ upstream from the sewage outlet of the city Velika Gorica $(\mathrm{n}=9) ; 3 \mathrm{~b}-0.5 \mathrm{~km}$ downstream from the sewage outlet of the city Velika Gorica $(\mathrm{n}=9) ; 3 \mathrm{c}-$ Oborovo $(\mathrm{n}=11) ; 4$ - Lukavec Posavski $(\mathrm{n}=8))$. The results are presented as box-plots which boundaries indicate $25^{\text {th }}$ and $75^{\text {th }}$ percentiles; a line within the box marks the median value; whiskers above and below the box indicate $10^{\text {th }}$ and $90^{\text {th }}$ percentiles, whereas dots indicate outliers. Differences among sites are indicated with different letters $(a, b)$, based on Kruskal-Wallis one way analysis of variance on ranks ( $p$-values indicated within the figures) and post hoc Dunn's test $(p<0.05)$.

Dissolved metal concentrations in the surface water of the Sava River in spring 2006 showed the following increasing order: $\mathrm{Cd}\left(0.003-0.020 \mu \mathrm{g} \mathrm{L}^{-1}\right)<\mathrm{Co}$ $\left(0.023-0.136 \mu \mathrm{g} \mathrm{L}^{-1}\right)<\mathrm{Pb}\left(0.003-0.234 \mu \mathrm{g} \mathrm{L}^{-1}\right)<\mathrm{Cr}\left(0.068-0.426 \mu \mathrm{g} \mathrm{L}^{-1}\right)<\mathrm{Cu}$ $\left(0.055-0.881 \mu \mathrm{g} \mathrm{L}^{-1}\right)<\mathrm{Ni}\left(0.307-1.07 \mu \mathrm{g} \mathrm{L}^{-1}\right)<\mathrm{Zn}\left(0.089-8.74 \mu \mathrm{g} \mathrm{L}^{-1}\right)<\mathrm{Mn}(0.352-$ $\left.14.72 \mu \mathrm{g} \mathrm{L}^{-1}\right)<\mathrm{Fe}\left(0.646-44.52 \mu \mathrm{g} \mathrm{L}^{-1}\right)$ (Dragun et al. 2009c). The analysis of spatial variability indicated increased concentrations of $\mathrm{Co}, \mathrm{Fe}$, and $\mathrm{Mn}$ at the sites influenced by point sources of pollution (municipal and industrial wastewater outlets of cities of Zagreb, Velika Gorica, and Sisak) (Fig. 3b,e,f). The previous investigations indicated that the untreated wastewater of Zagreb city present a significant source of metal input into the Sava River (Mikac and Branica 1994; Dautović, 2006). The highest concentrations of Mn and Co, as well as increased Fe concentrations were found immediately after the sewage outlet of the city of Velika 
Gorica. Dissolved concentrations of these three metals decreased with the distance from the point source of pollution. Due to their adsorption on suspended particles and subsequent precipitation, the increased concentrations of several metals can be expected rather in the river sediment than in the water (Koukal et al. 2004). The highest dissolved Fe concentrations (Fig. 3e), on the other hand, were found at Lukavec Posavski, downstream from the industrial centre of the city of Sisak, contrary to dissolved $\mathrm{Cd}$ (Fig. 3a) and $\mathrm{Cr}$ (Fig. 3c) which concentrations were the lowest at that site. The concentrations of $\mathrm{Cu}, \mathrm{Ni}, \mathrm{Pb}$, and $\mathrm{Zn}$ (Fig. 3d,g,h,i) have not differed notably between sites (Dragun et al. 2009c).

Above presented concentrations were comparable with previously reported dissolved metal concentrations for the same section of the Sava River (in January 2005, in $\mu \mathrm{g} \mathrm{L}^{-1}$ : Cd 0.015, Co 0.068, Pb 0.045, Cr 0.590, Cu 1.27, Ni 0.56, Zn 2.77, Mn 8.72, Fe 14.10; Dautović 2006; Dautović et al. 2007). However, they were generally slightly above the concentrations reported for some unpolluted rivers in Croatia, such as Krka (in $\mu \mathrm{g} \mathrm{L}^{-1}$ : Cd 0.005, Pb 0.017, Cu 0.11, Ni 0.15, Fe 1.35; Elbaz-Poulichet et al. 1991) and Una (in $\mu \mathrm{g} \mathrm{L}^{-1}$ : Cd 0.005, Co 0.016, Pb 0.077, Cr 0.15, Cu 0.10, Ni 0.14, Zn 0.22, Mn 1.64, Fe 1.63; Dautović 2006; Dautović et al. 2007), indicating certain level of anthropogenic impact on the Sava River. On the other hand, comparison with the environmental quality standards (EQS) set by European Water Framework Directive (EPCEU 2008) revealed that the concentrations of several dissolved metals were still below recommended levels for inland surface waters. The highest dissolved Cd concentration in the Sava River was approximately 4 times lower than the strictest EQS defined for $\mathrm{Cd}\left(\leq 0.080 \mu \mathrm{g} \mathrm{L}^{-1}\right)$. The highest dissolved $\mathrm{Pb}$ and $\mathrm{Ni}$ concentrations were 30 and 18.5 times lower than

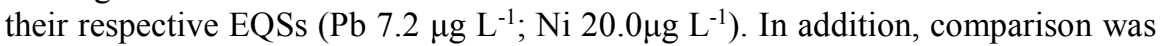
made with Canadian water quality guidelines for the protection of aquatic life, which are derived based on a goal of no observable adverse effects on aquatic ecosystems over the long term (calculated taking in consideration the concentration of $\mathrm{CaCO}_{3}$ in the water: $\mathrm{Cd} 0.067 \mu \mathrm{g} \mathrm{L}^{-1} ; \mathrm{Pb} 7.0 \mu \mathrm{g} \mathrm{L}^{-1} ; \mathrm{Cu} 4.0 \mu \mathrm{g} \mathrm{L}^{-1} ; \mathrm{Ni} 150 \mu \mathrm{g} \mathrm{L}^{-}$ 1; $\mathrm{Zn} 30.0 \mu \mathrm{g} \mathrm{L}^{-1}$; Fe $300 \mu \mathrm{g} \mathrm{L}{ }^{-1}$; http://st-ts.ccme.ca/). These recommendations were higher from 3 (for $\mathrm{Cd}$ and $\mathrm{Zn}$ ) to 140 times (for $\mathrm{Ni}$ ) than dissolved metal concentrations in the Sava River water. And finally, the average levels of dissolved $\mathrm{Cr}$ concentrations were lower than limits defined for unpolluted freshwaters $(<2 \mu \mathrm{g}$ $\mathrm{L}^{-1}$; Pawlisz et al. 1997). Based on the presented data, the water of the studied section of the Sava River could be considered as only weakly contaminated with metals and still environmentally acceptable.

\section{Labile metal concentrations in the Sava River water measured by diffusive gradient in thin films (DGT)}

Although the dissolved metal concentrations provide valuable information on water quality, the fact that they are commonly based on grab water sampling with a frequency of once or twice a month presents a serious problem for reliable assessment of water contamination, because some elements are characterized by high short-term temporal variability. This was observed for several metals measured 
in the Sava River water, with the highest average relative standard deviation within a site obtained for $\mathrm{Mn}(104 \%$, Fig. 3f), then $\mathrm{Pb}, \mathrm{Zn}$ and $\mathrm{Fe}(94 \%, 65 \%, 45 \%$, respectively; Fig. 3h,i,e; Dragun et al. 2009c).

This problem could be overcome by application of passive samplers for metals, i.e. diffusive gradient in thin films (DGT). They facilitate determination of the time-integrated average metal concentrations after long-term deployment in natural waters (Zhang and Davison 1995). They also provide an advantage of determining exclusively the labile metal species in natural waters (Davison and Zhang 1994) which are very often associated to the biological response in aquatic organisms (Campbell 1995). DGT method is based on the diffusion of dissolved metal species through a polyacrylamide gel and their immobilization in a chelating (Chelex) resin (Zhang and Davison 1995).The kinetically inert organic species are excluded by this method, as well as large colloids, because the pore size of 2-5 nm in diffusive gel does not enable their diffusion (Zhang and Davison 1995).

The measurement of labile metal species in the Sava River water was performed during autumn of 2005, at the same sites as measurement of the dissolved metals. The commercially available DGTs (diffusive gel thicknesses either $0.76 \mathrm{~mm}$ or $0.84 \mathrm{~mm}$; DGT Research Ltd., UK; Davison and Zhang 2002) were deployed 12 times per site, for few weeks (in total 22-33 days), in the period from October 10 to November 11 (Dragun et al. 2008). During the entire deployment period, temperature was recorded continuously using temperature data loggers StowAway ${ }^{\circledR}$ Tidbit ${ }^{\circledR}$ (Onset Computer Corporation) which enabled the precise determination of the average water temperature and thereby also of the diffusion coefficients for each metal in each deployment period.

The concentrations of nine metals ( $\mathrm{Cd}, \mathrm{Co}, \mathrm{Cr}, \mathrm{Cu}, \mathrm{Fe}, \mathrm{Mn}, \mathrm{Ni}, \mathrm{Pb}$, and $\mathrm{Zn}$ ) were determined in the eluent acid $\left(1 \mathrm{M} \mathrm{HNO}_{3}\right)$ obtained after $24 \mathrm{~h}$ elution of Chelex resin taken from DGTs, which were retrieved from the river water. The measurements were performed by two methods: 1) atomic absorption spectrometry (AAS, Varian SpectrAA 220, Australia), using flame technique for Fe, Mn and Zn, and electrothermal technique for $\mathrm{Cd}, \mathrm{Co}, \mathrm{Cr}, \mathrm{Cu}$, and $\mathrm{Ni}$, and 2) HR ICP-MS (Element 2, Thermo Finnigan, Germany) for $\mathrm{Pb}$ and for the lowest $\mathrm{Cr}$ concentrations. Based on the metal concentrations determined in the eluent acid $\left(C_{e}\right)$, the masses of the metals accumulated on the ion-exchange resin $(M)$ were calculated according to the equation [1], in which $V_{r}$ stands for the resin volume, $V_{e}$ for the eluent volume, and $f_{e}$ for the elution factor. The concentrations of the labile metal species in the river water $\left(C_{D G T}\right)$ were then calculated using the equation [2], in which $\Delta g$ represents the joint thickness of the diffusive gel and the membrane filter, $\delta$ represents the diffusive boundary layer, $D$ is the diffusion coefficient of the metal in the gel at the defined temperature, $A$ is the effective diffusion area, and $t$ is the deployment time (Zhang and Davison 1995). The diffusive boundary layer is a layer of water adjacent to all solid surfaces where flow velocity approaches zero (Santschi et al. 1983). It is presumably negligible in the fast flowing waters, i.e. above a low threshold water flow of $0.02 \mathrm{~m} \mathrm{~s}^{-1}$ (Gimpel et al. 2001). Since the Sava 
River is a fast flowing river ( $0.5 \mathrm{~m} \mathrm{~s}^{-1}$ at low water-level; Terek 2004$)$, the thickness of the diffusive layer in our calculations was equal to $\Delta g$ value (Dragun et al. 2008).

$$
M=\frac{C_{e} \times\left(V_{r}+V_{e}\right)}{f_{e}} \quad[1] \quad C_{D G T}=\frac{M \times(\Delta g+\delta)}{D \times A \times t}
$$
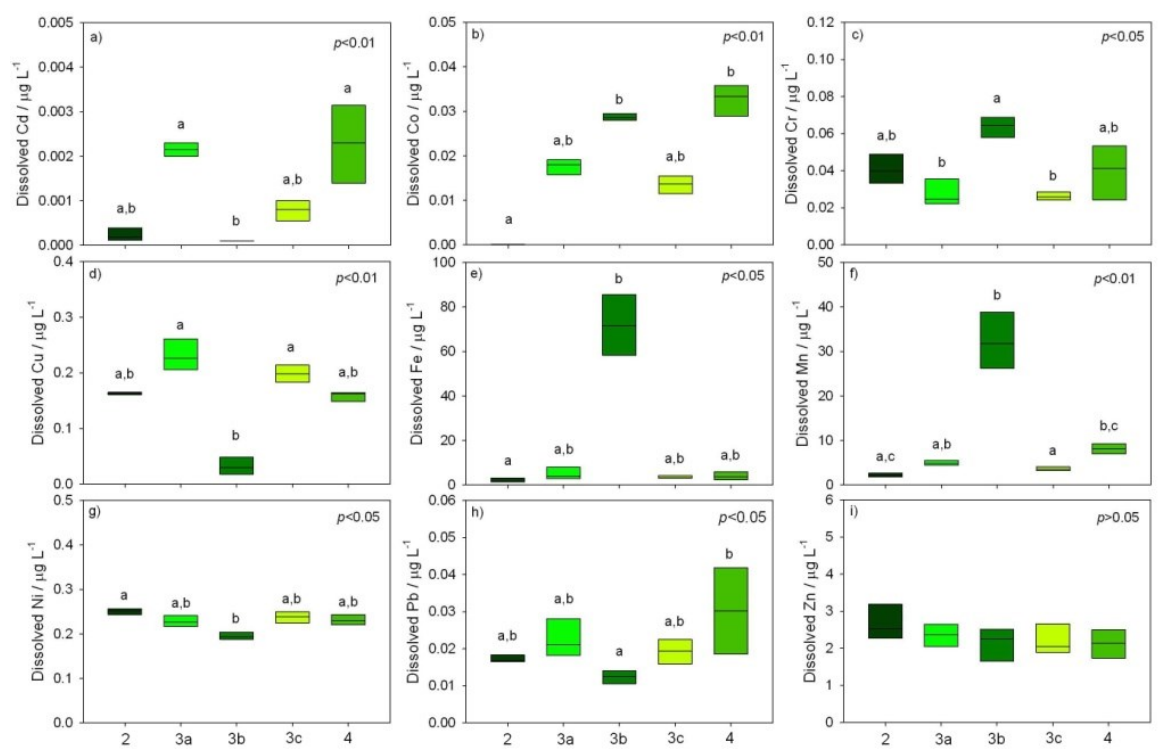

Figure 4. Spatial distribution of the concentrations of the labile species of nine dissolved trace elements in the Sava River water measured by DGT (diffusive gradient in thin films), in the period from October 10 to November 11, 2005, at five sampling sites. The site legend and the results are presented as indicated in the Fig. 3. Each box-plot is based on the results obtained by deployment of 4 DGTs.

The DGT-labile metal concentrations measured in the Sava River during October/November of 2005 were considerably lower than dissolved metal concentrations, but showed similar increasing order: $\mathrm{Cd}\left(0.0001-0.0032 \mu \mathrm{g} \mathrm{L}^{-1}\right)<$ $\mathrm{Co}\left(0.0001-0.037 \mu \mathrm{g} \mathrm{L}^{-1}\right)<\mathrm{Pb}\left(0.009-0.044 \mu \mathrm{g} \mathrm{L}^{-1}\right)<\mathrm{Cr}\left(0.019-0.071 \mu \mathrm{g} \mathrm{L}^{-1}\right)<\mathrm{Cu}$ $\left(0.017-0.276 \mu \mathrm{g} \mathrm{L}^{-1}\right) \leq \mathrm{Ni}\left(0.187-0.257 \mu \mathrm{g} \mathrm{L}^{-1}\right)<\mathrm{Zn}\left(1.28-3.80 \mu \mathrm{g} \mathrm{L}^{-1}\right)<\mathrm{Mn}(1.74-$ $\left.42.01 \mu \mathrm{g} \mathrm{L}^{-1}\right)<\mathrm{Fe}\left(1.21-90.01 \mu \mathrm{g} \mathrm{L}^{-1}\right)$ (Dragun et al. 2008). The increased labile concentrations of $\mathrm{Co}, \mathrm{Cr}, \mathrm{Fe}$ and $\mathrm{Mn}$ (Fig. 4b,c,e,f) were found downstream of the sewage outlet of the city Velika Gorica. At that site, DGTs were deployed in the river water during the prolonged period of low water-level, and the concentration increase was probably a consequence of the sewage material preconcentration combined with oxygen depletion (oxygen saturation: $22 \pm 27 \%$; Dragun et al. 2008). Low oxygen level usually accompanies the increase of the content of dissolved 
organic matter in the water due to enhanced oxygen consumption by bacteria in the process of organic matter biodegradation (Harrison 1995; Koukal et al. 2004). It consequently leads to the reduction of $\mathrm{Mn}$ and Fe oxides, which could explain increase of their labile forms, as well as the labile forms of associated metals in the river water (Elbaz-Poulichet et al. 2006).

Contrary, the labile concentrations of $\mathrm{Cd}, \mathrm{Cu}, \mathrm{Ni}$, and $\mathrm{Pb}$ were decreased at that same site (Fig. 4a,d,g,h), which could be a consequence of the formation of inert complexes with dissolved organic matter in the river water. Such occurrence is especially characteristic for $\mathrm{Cd}$ and $\mathrm{Cu}$. Copper complexes with organic matter, for example, are more inert compared to the complexes formed by the majority of other bivalent metal ions (Sigg and Xue 1994). Similar to our study, low levels of labile species of several metals were also reported for the Lambro River, at the highly contaminated site near Milan, due to high concentration of organic material (Garofalo et al. 2004). Somewhat increased concentrations of the labile species of $\mathrm{Cd}, \mathrm{Co}$ and $\mathrm{Pb}$ were observed at the site impacted by industrial wastewaters, Lukavec Posavski (Fig. 4a,b,h). Nevertheless, with the exception of the labile concentrations of some metals downstream of the sewage outlet (e.g. Fe and Mn) during the dry mid-autumn season, the average DGT-labile concentrations of nine analyzed metals in the surface water of the selected section of the Sava River were comparable to the concentrations previously reported for the rivers regarded as unpolluted (e.g. river Wyre, Sigg et al. 2006; Dragun et al. 2008).

\section{Metal bioaccumulation in three tissues of bioindicator organism}

For the assessment of the metal bioavailability, it is not enough to measure the metal concentrations in the river water, but it is also important to define the level of metal bioaccumulation in the tissues of aquatic organisms caused by determined level of exposure. Among aquatic organisms, fish are often used as bioindicators. They are one of the most indicative species in freshwater systems, for the estimation of trace metal pollution and possible risk to human health. From the ecological point of view, they are at the top of the aquatic food chain, and therefore mirror the combination of the biotic and abiotic conditions in the particular aquatic environment. In addition, their size and mass of their organs enable numerous analyses, while their long life span results in a pronounced metal accumulation (Chovanec et al. 2003). Among fish communities inhabiting the sampled section of the Sava River, European chub (S. cephalus L.; Fig. 5) was selected as an indicator species for the assessment of metal bioavailability. It is a fish species from the family of carps (Cyprinidae), widespread in the European freshwater and tolerant to chemical and physical pollution (Gandolfi et al. 1991). European chub is an omnivorous fish species, which feeds on algae, plants and various seeds (Vostradovsky 1973), as well as worms, molluscs, crayfish and insect larvae, whereas larger chub specimens also eat different species of small fish (Maitland and Campbell 1992). Therefore, metal analyses in the chub organs can reflect the combined metal uptake from water, as well as both plant and animal food sources. 
Table 2. The biometric data (length, total mass, Fulton condition index (FCI), gonadosomatic index (GSI), percentage of females (F) and age) for the chub $(S$. cephalus) sampled in the Sava River at five sites (1 - Otok Samoborski, $\mathrm{n}=15 ; 2$ Zagreb, $\mathrm{n}=18 ; 3$ - Oborovo, $\mathrm{n}=13$; 4 - Lukavec Posavski, $\mathrm{n}=1$ 5; 5 - Jasenovac, $\mathrm{n}=15$ ) in April/May of 2006.

\begin{tabular}{|ccccccc|}
\hline & Length & Total mass & FCI & GSI & F & Age \\
& $/ \mathbf{c m}$ & $/ \mathbf{g}$ & $/ \mathbf{g ~ c m}^{-3}$ & $/ \mathbf{\%}$ & $/ \%$ & $/$ years \\
$\mathbf{1}$ & $17.41 \pm 2.24$ & $55.62 \pm 25.07$ & $0.99 \pm 0.07$ & $1.57 \pm 1.94$ & 53.3 & $2.4 \pm 0.5$ \\
$\mathbf{2}$ & $18.66 \pm 2.82$ & $72.54 \pm 40.59$ & $1.03 \pm 0.07$ & $0.60 \pm 0.58$ & 66.7 & $2.6 \pm 0.7$ \\
$\mathbf{3}$ & $19.99 \pm 3.11$ & $92.13 \pm 42.44$ & $1.07 \pm 0.09$ & $0.97 \pm 1.22$ & 84.6 & $2.8 \pm 0.8$ \\
$\mathbf{4}$ & $17.85 \pm 1.75$ & $68.29 \pm 23.64$ & $1.16 \pm 0.12$ & $0.80 \pm 1.22$ & 46.7 & $2.7 \pm 0.5$ \\
$\mathbf{5}$ & $20.49 \pm 1.63$ & $95.95 \pm 26.75$ & $1.08 \pm 0.07$ & $0.54 \pm 0.15$ & 53.3 & $2.8 \pm 0.6$ \\
\hline
\end{tabular}

Table 3. The biometric data (length, total mass, Fulton condition index (FCI), gonadosomatic index (GSI), percentage of females (F) and age) for the chub $(S$. cephalus) sampled in the Sava River at five sites ( 1 - Otok Samoborski, $n=15 ; 2$ Zagreb, n=14; 3 - Oborovo, $n=10 ; 4$ - Lukavec Posavski, n=10; 5 - Jasenovac, $n=10$ ) in September of 2006.

\begin{tabular}{|ccccccc|}
\hline & Length & Total mass & FCI & GSI & F & Age \\
& \multicolumn{1}{c}{$\mathbf{c m}$} & $/ \mathbf{g}$ & $/ \mathbf{g ~ c m}^{-3}$ & $/ \mathbf{\%}$ & $/ \%$ & $/$ years \\
\cline { 2 - 6 } $\mathbf{1}$ & $23.90 \pm 2.98$ & $144.84 \pm 58.23$ & $1.01 \pm 0.06$ & $0.66 \pm 0.23$ & 76.9 & $3.0 \pm 0.7$ \\
$\mathbf{2}$ & $17.86 \pm 3.12$ & $57.99 \pm 33.49$ & $0.92 \pm 0.08$ & $0.54 \pm 0.18$ & 91.7 & $2.0 \pm 0.8$ \\
$\mathbf{3}$ & $18.65 \pm 4.00$ & $68.59 \pm 50.13$ & $0.92 \pm 0.07$ & $0.59 \pm 0.12$ & 55.6 & $2.6 \pm 0.7$ \\
$\mathbf{4}$ & $20.60 \pm 4.04$ & $92.27 \pm 55.96$ & $0.94 \pm 0.09$ & $0.55 \pm 0.23$ & 40.0 & $3.3 \pm 0.7$ \\
$\mathbf{5}$ & $26.85 \pm 2.43$ & $194.92 \pm 58.46$ & $0.98 \pm 0.05$ & $0.47 \pm 0.17$ & 60.0 & $3.9 \pm 0.7$ \\
\hline
\end{tabular}

Based on the fact that gonad development in the fish is related to increments in the daylight period, water temperature, and food supply (Encina and Granado-Lorencio 1997), the exact period of S. cephalus spawning depends on the climate, and in the Sava River occurs from April to June (Habeković et al. 1993). Sampling campaigns at five sampling sites along the Sava River (Fig. 1) were, therefore, conducted in April/May and September 2006, as representative periods of the chub spawning and post-spawning, respectively. The biometric data for the sampled chub are presented separately for each sampling site in the Table 2 
(April/May) and Table 3 (September). In April/May campaign, 76 chub specimens of the following biometric characteristics were sampled: length 14.7-27.0 cm, total mass 29.6-205.1 g, Fulton condition index $0.88-1.35 \mathrm{~g} \mathrm{~cm}^{-3}$ and gonadosomatic index 0.22-6.92\%. In September campaign, 59 chub specimens of the following biometric characteristics were sampled: length $13.5-31.5 \mathrm{~cm}$, total mass $20.1-312.7$ $\mathrm{g}$, Fulton condition index $0.79-1.12 \mathrm{~g} \mathrm{~cm}^{-3}$ and gonadosomatic index $0.15-1.09 \%$. In both sampling periods, 2 and 3 years old chub were predominant in the sampled group, although in April/May 2-5 year old specimens and in September 1-5 year old specimens were collected. Representation of females was $60.5 \%$ in April/May sampling and $66.7 \%$ in September sampling.

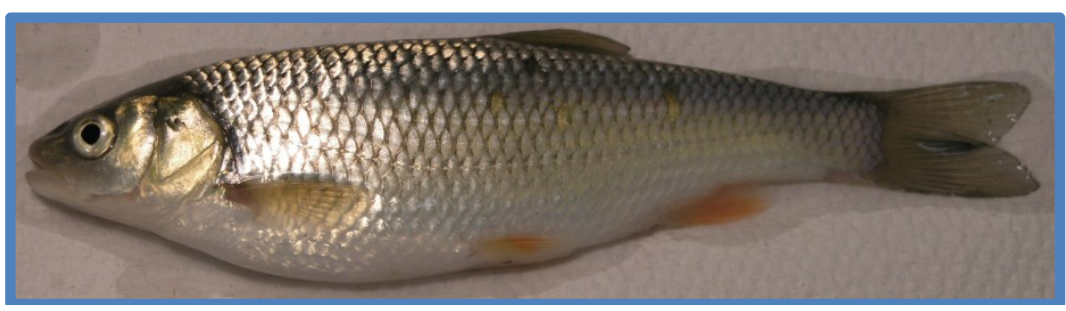

Figure 5. European chub (Squalius cephalus L.) from the Sava River.

Metals are taken up in the fish through skin, gills and gastrointestinal tract and consequently the pattern of metal distribution among fish organs is dependent on the route of metal uptake. Three chub organs were, accordingly, selected for metal analyses: the liver (Podrug and Raspor 2009; Podrug et al. 2009), the gills (Dragun et al. 2007; Dragun et al. 2009a), and the gastrointestinal tissue (Filipović Marijić and Raspor 2010; Filipović Marijić and Raspor 2012). Liver is the main detoxification and storage organ, which could reflect metal accumulation caused by chronic exposure. Gills and gastrointestinal tissue, on the other hand, present main uptake sites for metals in freshwater fish, through water filtration and food consumption, respectively (Heath 1995). These two organs are in direct contact with the ambient water and ingested food, and therefore they are expected to respond quickly to changes in the metal exposure (Kraemer et al. 2005). The concentrations of essential metals $\mathrm{Cu}, \mathrm{Fe}, \mathrm{Mn}$, and $\mathrm{Zn}$, and nonessential metal $\mathrm{Cd}$ were measured in the soluble tissue fractions and not in the whole digested tissues, as common in the environmental studies. The aim of such approach was to obtain the information on the portion of metal which is presumably available for the interactions with vital cell components and consequently could cause toxic effects (Dragun et al. 2012). The soluble tissue fractions were obtained by tissue homogenisation in the cold homogenising buffer $\left(100 \mathrm{mM}\right.$ Tris- $\mathrm{HCl} /$ Base buffer; $\mathrm{pH} 8.1$ at $\left.4^{\circ} \mathrm{C}\right)$, followed by centrifugation at $50,000 \times \mathrm{g}$ for $2 \mathrm{~h}$ at $4^{\circ} \mathrm{C}$. The resulting supernatant corresponded to the cytosolic fraction, in which metal measurements were performed by electrothermal and flame AAS (Varian, SpectrAA 220, Australia; Dragun et al. 2007; Dragun et al. 2009a; Podrug and Raspor 2009; Podrug et al. 2009; Filipović Marijić and Raspor 2010; Filipović Marijić and Raspor 2012). 


\subsection{Metal bioaccumulation in the chub liver}

The fish liver was shown to be the main target organ for accumulation of some metals, such as $\mathrm{Cu}$ and $\mathrm{Cd}$ (Olsvik et al. 2001; Giguère et al. 2004; Van Campenhout et al. 2004; Filipović Marijić and Raspor 2007). However, since both dissolved and labile metal concentrations within the selected section of the Sava River were reported as comparable with the levels characteristic for unpolluted rivers (Dragun et al. 2008 and 2009a,c), fish from the Sava River were subjected to relatively low metal exposure. The concentrations of trace elements in the hepatic cytosol of chub from this river were, therefore, regarded as constitutive for specific periods, April/May as a representative of spawning period, and September as a representative of post-spawning period. In both sampling periods, trace elements had the same decreasing order: $\mathrm{Fe}>\mathrm{Zn}>\mathrm{Cu}>\mathrm{Mn}>\mathrm{Cd}$ (Podrug and Raspor 2009; Podrug et al. 2009).

The following concentration ranges were determined in April/May and September, respectively: Fe (2.04-14.16 $\mu \mathrm{g} \mathrm{mL}^{-1}$ and 2.10-7.16 $\left.\mu \mathrm{g} \mathrm{mL}^{-1}\right), \mathrm{Zn}(2.88$ $11.83 \mu \mathrm{g} \mathrm{mL}^{-1}$ and 2.72-6.90 $\left.\mu \mathrm{g} \mathrm{mL}^{-1}\right), \mathrm{Cu}\left(0.295-3.66 \mu \mathrm{g} \mathrm{mL}^{-1}\right.$ and 0.435-5.13 $\mu \mathrm{g}$ $\left.\mathrm{mL}^{-1}\right), \mathrm{Mn}\left(157.5-405.0 \mathrm{ng} \mathrm{mL}^{-1}\right.$ and 100.0-337.5 $\left.\mathrm{ng} \mathrm{mL}^{-1}\right)$, and $\mathrm{Cd}(1.17-20.86 \mathrm{ng}$ $\mathrm{mL}^{-1}$ and 2.30-25.10 $\mathrm{ng} \mathrm{mL}^{-1}$ ). Although three elements, Fe, $\mathrm{Zn}$ and $\mathrm{Mn}$ had reached higher maximal values in the spring period, statistically significant difference between two sampling periods was obtained only for Mn $(p<0.001$, Mann-Whitney rank sum test). Elevated concentrations of some essential metals, such as Fe, Mn and $\mathrm{Zn}$, in the chub hepatic cytosol in the spring period could be ascribed to the processes connected to the reproductive cycle, as reported for red mullet (Mullus barbatus; Miramand et al. 1991; Filipović Marijić and Raspor 2008). General increase in the fish metabolism before and during the reproductive period is reflected in increased hepatic metal levels since essential metals form active parts of proteins/enzymes (Miramand et al. 1991). Karadede and Ünlü (2007) also observed higher Mn concentrations in the spring in the whole liver tissue of freshwater fish Silirus tristegus, as well as higher concentrations of both $\mathrm{Mn}$ and $\mathrm{Zn}$ in the freshwater fish Mastacembelus simacks.

Analysis of spatial distribution pointed to slight accumulation in the cytosol of chub liver only for $\mathrm{Cd}$ (Fig. 6a,b) and $\mathrm{Cu}$ (Fig. 6c,d) at the most downstream site, Jasenovac, and it was more prominent in September than in April/May sampling. Similarly, Kraemer et al. (2005) reported more pronounced accumulation of $\mathrm{Cd}$ and $\mathrm{Cu}$ than $\mathrm{Zn}$ in the liver tissue of yellow perch from metalcontaminated Lake Dufault (Canada). Andres et al. (2000) observed increased Cd accumulation in the chub liver at the site close to the zinc ore treatment facility, whereas $\mathrm{Zn}$ concentrations varied only slightly. Since dissolved $\mathrm{Cd}$ and $\mathrm{Cu}$ concentrations in the Sava River water were comparable at all sampling sites (Dragun et al. 2009c), dietary and not only waterborne metal uptake should be considered as a possible source of slight, but statistically significant, increase of hepatic $\mathrm{Cd}$ and $\mathrm{Cu}$ concentrations at Jasenovac. It could be associated with the specific impacts of the industrial facility, possibly with the input of pyrolytic and 
petrogenic hydrocarbons from the oil-refinery situated in the city of Sisak. However, it should be also emphasized that in September the oldest and the biggest fish were caught at Jasenovac (Table 3), and, therefore, higher $\mathrm{Cd}$ and $\mathrm{Cu}$ accumulation compared to the other sites could partly be a reflection of longer exposure period.
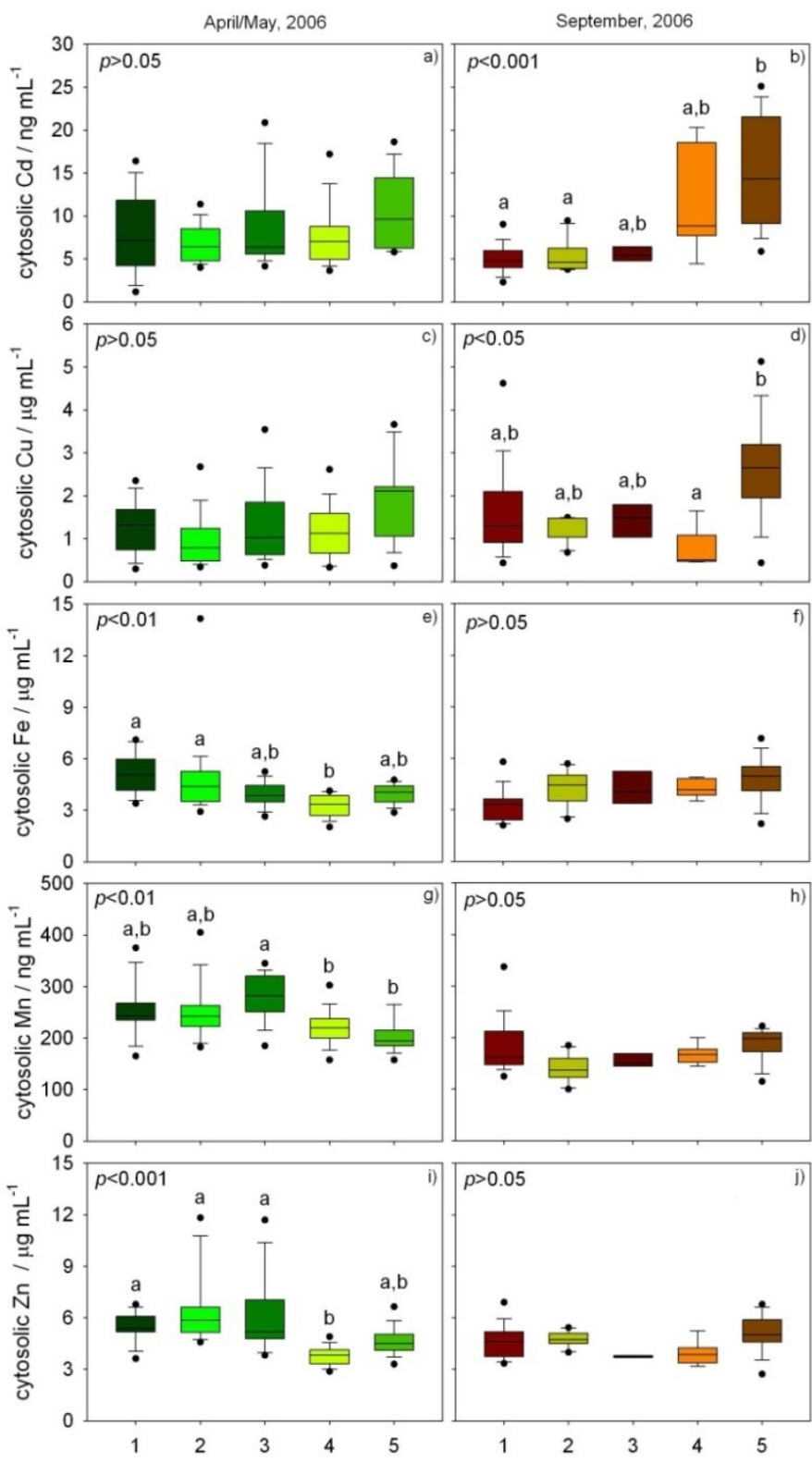
Figure 6. Spatial distribution of the cytosolic concentrations of five trace elements in the liver of the chub caught in the Sava River in two periods, April/May and September 2006, at five sampling sites $(1-$ Otok Samoborski $(n=8$ and 14 , respectively); 2 - Zagreb ( $\mathrm{n}=15$ and 6 , respectively); 3 - Oborovo ( $\mathrm{n}=11$ and 4 , respectively); 4 - Lukavec Posavski ( $\mathrm{n}=12$ and 5, respectively); 5 - Jasenovac $(\mathrm{n}=11$ and 10 , respectively)). The results are presented as indicated in the Fig. 3.

Contrary, essential elements Fe, Mn and Zn were slightly increased at three upstream sites, but only in the spring sampling (Fig. 6e,g,i). In September, their concentrations were comparable at all sites (Fig. 6f,h,j). Although fish in this study were young and mostly not sexually mature, several of them had increased GSIs in the spring period, which was especially evident at the upstream sites (Table 2). The cause of the increase of essential elements at upstream sites, therefore, could be their role in metabolic processes and gonad development, and not necessarily the increased exposure in the river water.

\subsection{Metal bioaccumulation in the chub gills}

Contrary to metal concentrations in the liver, which represent long-term storage of metals, metal concentrations in the gills are expected to reflect short-term metal exposure in the water (Roméo et al. 1999). Therefore, they should be a good indicator of the sudden changes in the metal exposure (Kraemer et al. 2005). In the chub gills, cytosolic concentrations of trace elements had the following decreasing order in both sampling periods: $\mathrm{Zn} \geq \mathrm{Fe}>\mathrm{Cu}=\mathrm{Mn}>\mathrm{Cd}$ (Dragun et al. 2007; Dragun et al. 2009a). The following concentration ranges were determined in April/May and September, respectively: $\mathrm{Zn}\left(5.30-16.19 \mu \mathrm{g} \mathrm{mL}^{-1}\right.$ and 3.60-14.67 $\mu \mathrm{g}$ $\left.\mathrm{mL}^{-1}\right), \mathrm{Fe}\left(2.28-16.61 \mu \mathrm{g} \mathrm{mL}^{-1}\right.$ and 3.14-8.36 $\left.\mathrm{g} \mathrm{mL}^{-1}\right), \mathrm{Cu}\left(40.42-181.97 \mathrm{ng} \mathrm{mL}^{-1}\right.$ and 19.58-56.91 $\left.\mathrm{ng} \mathrm{mL}^{-1}\right)$, Mn (33.87-103.59 $\mathrm{ng} \mathrm{mL}^{-1}$ and 28.23-82.49 $\mathrm{ng} \mathrm{mL}^{-1}$ ), and $\mathrm{Cd}\left(1.30-26.60 \mathrm{ng} \mathrm{mL} \mathrm{m}^{-1}\right.$ and $\left.0.83-2.12 \mathrm{ng} \mathrm{mL}^{-1}\right)$. All five elements had statistically significantly higher values in the spring period than autumn $(p<0.001$, Mann-Whitney rank sum test). Cadmium and $\mathrm{Cu}$ were twice higher, whereas Fe, $\mathrm{Mn}$ and $\mathrm{Zn}$ were $90 \%, 50 \%$ and $40 \%$ higher in the spring, respectively. The seasonal changes of metal concentrations in the fish tissues can arise due to the changes of the feeding and growth rate, as well as the result of the changes in the fish condition (McCoy et al. 1995; Farkas et al. 2002). The metal concentrations, especially for essential metals like $\mathrm{Zn}$, increase following the increase of the metabolic activity (Andres et al. 2000). Therefore, it can be hypothesized that the observed increase of all measured metals in the gill cytosol of chub in April/May sampling was the consequence of higher metabolic and feeding rates in the spring period than autumn (Dragun et al. 2007). It could be further supported by generally higher spring than autumn Fulton condition indices (Tables 2 and 3), which reflect the energy reserves and give the information about the recent feeding activity (Lambert and Dutil 1997).

The analysis of the spatial distribution of cytosolic metal concentrations in the chub gills indicated generally more pronounced differences between sites in the spring period (Fig. 7). It could be possibly associated to implied increase of water 
filtration and feeding rates in the spring period, which could further lead to increased uptake of metals, and finally to easier identification of metalcontaminated sites.

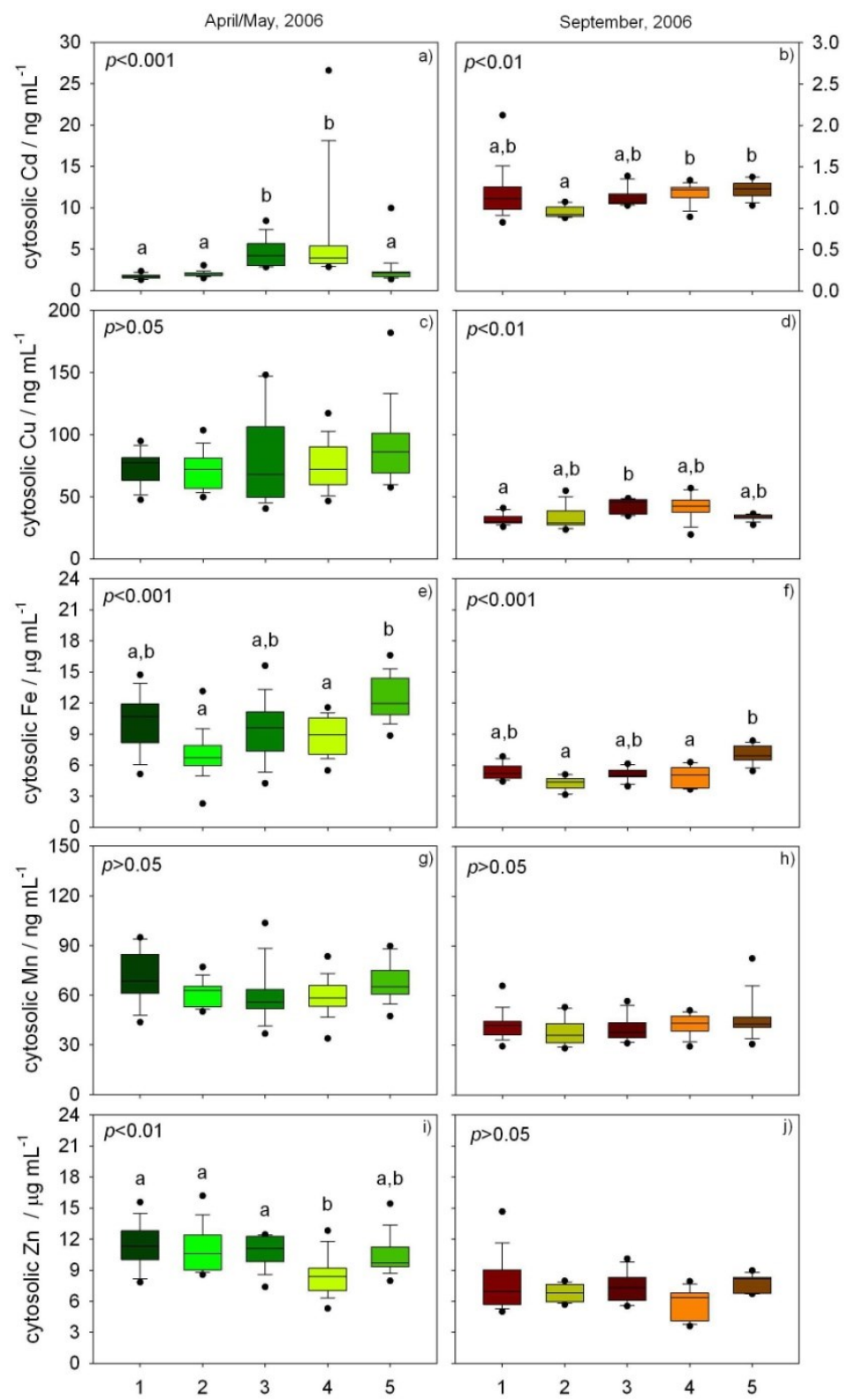

Figure 7. Spatial distribution of the cytosolic concentrations of five trace elements in the gills of the chub caught in the Sava River in two periods, April/May and 
September 2006, at five sampling sites ( 1 - Otok Samoborski ( $\mathrm{n}=10$ and 13 , respectively); 2 - Zagreb ( $\mathrm{n}=14$ and 10, respectively); 3 - Oborovo ( $\mathrm{n}=12$ and 7 , respectively); 4 - Lukavec Posavski ( $\mathrm{n}=15$ and 9, respectively); 5 - Jasenovac $(\mathrm{n}=14$ and 10, respectively)). The results are presented same as indicated in the Fig. 3 .

Increase towards the downstream sites was observed for three metals: $\mathrm{Cd}$, $\mathrm{Cu}$ and Fe (Dragun et al. 2009a). The concentrations of $\mathrm{Cd}$ were the highest at Oborovo and Lukavec Posavski in the spring (Fig. 7a), whereas the increase was shifted towards more downstream sites in September (Lukavec Posavski and Jasenovac; Fig. 7b). For nonessential metals, such as $\mathrm{Cd}$, the concentration gradient in the water can be also expected in the fish organs (Andres et al. 2000) because $\mathrm{Cd}$ tissue concentrations are independent of strict physiological control, which is characteristic for the majority of essential metals (Sorensen 1991). Therefore, it can be assumed that higher $\mathrm{Cd}$ concentrations measured in the fish gills at the specific sites were the reflection of higher Cd bioavailability in the ambient water. However, dissolved and labile $\mathrm{Cd}$ concentrations were very low in the Sava River water $(\leq 20$ ng L ${ }^{-1}$ and $\leq 3 \mathrm{ng} \mathrm{L}^{-1}$, respectively) at all analyzed sampling sites (Fig. 3 and 4). Although $\mathrm{Cd}$, as a nonessential metal, tends to accumulate in tissues of aquatic organisms even at relatively low water concentrations, in water with low metal levels, metal uptake from the food prevails (Dallinger and Kautzky 1985). This is also a possible explanation for increased cytosolic Cd at downstream sites observed in our study.

The differences in $\mathrm{Cu}$ concentrations between sites were less prominent, but slight increase was observed at Oborovo (Fig. 7c,d). Slight increase of Fe concentrations was also recorded at Oborovo, but the highest values were measured at the most downstream site Jasenovac in both samplings (Fig. 7e,f). The dissolved and labile $\mathrm{Fe}$ concentrations in the river water were also increased at Oborovo compared to Zagreb (Fig. 3e and 4e), whereas they were not determined in the river water at Jasenovac, thus disabling the comparison between the metal exposure and the highest cytosolic $\mathrm{Fe}$ measured at that site. In addition, the significant age dependence was previously observed for $\mathrm{Fe}$, with the 4-year-old fish having significantly higher $\mathrm{Fe}$ concentrations compared to juvenile, 2-3-year-old fish (Dragun et al. 2007). The increase of Fe concentrations, therefore, could be partially attributed to chub age at Jasenovac, since the sampled fish at that site were on average older and bigger compared to the remaining sampling sites (Table 2-3). The concentrations of Mn (Fig. 7g,h) and Zn (Fig. 7i,j) varied less between sites, and only noticeable difference referred to the lowest $\mathrm{Zn}$ concentrations at Lukavec Posavski in both seasons. This can be explained by the fact that the concentrations of essential elements, such as $\mathrm{Cu}, \mathrm{Mn}$ and $\mathrm{Zn}$, are generally efficiently regulated in the fish tissues by homeostatic processes, except at highly polluted sites (Sorensen 1991; Andres et al. 2000). For example, Andres et al. (2000) observed increased Zn concentrations in the chub gills after exposure to extremely high concentrations of dissolved $\mathrm{Zn}$ in River Lot water $\left(890 \mu \mathrm{g} \mathrm{L}^{-1}\right)$, but the increase was still not observed 
at a water $\mathrm{Zn}$ concentration of $45 \mu \mathrm{g} \mathrm{L}^{-1}$, which is still much higher than dissolved $\mathrm{Zn}$ concentrations in the Sava River water $\left(<5 \mu \mathrm{g} \mathrm{L}^{-1}\right.$; Dragun et al. 2009c).

\subsection{Metal bioaccumulation in the chub intestine}

There is a growing concern that dietborne metal uptake may be of equal or greater importance than the waterborne metal uptake for native fish (Campbell et al. 2005). In distinct contrast to seawater fish, freshwater fish drink negligible amounts of water. Consequently, in the gastrointestinal tract of freshwater fish primarily dietborne metals accumulate (Clearwater et al. 2000), which enables the application of digestive tract as an indicator organ for dietary metal exposure. In both sampling seasons, metal levels in the gastrointestinal cytosolic fraction of European chub followed the order: $\mathrm{Zn}>\mathrm{Fe}>\mathrm{Cu} \geq \mathrm{Mn}>\mathrm{Cd}$ (Fig. 8). The following concentration ranges were determined in April/May and September, respectively: $\mathrm{Cd}$ (3.94-244.9 $\mathrm{ng} \mathrm{mL}^{-1}$ and 1.78-181.8 $\left.\mathrm{ng} \mathrm{mL}^{-1}\right), \mathrm{Cu}\left(77.6-553.5 \mathrm{ng} \mathrm{mL}^{-1}\right.$ and 70.4$\left.498.0 \mathrm{ng} \mathrm{mL}^{-1}\right), \mathrm{Fe}\left(0.49-7.61 \mu \mathrm{g} \mathrm{mL}^{-1}\right.$ and $\left.0.58-3.16 \mu \mathrm{g} \mathrm{mL}^{-1}\right), \mathrm{Mn}(64.0-456.2 \mathrm{ng}$ $\mathrm{mL}^{-1}$ and $\left.43.6-281.8 \mathrm{ng} \mathrm{mL}^{-1}\right), \mathrm{Zn}\left(5.0-28.32 \mu \mathrm{g} \mathrm{mL}^{-1}\right.$ and $\left.4.96-15.58 \mu \mathrm{g} \mathrm{mL}^{-1}\right)$.

Comparison of the cytosolic metal concentrations between two sampling seasons indicated significantly higher levels of all five measured metals during the period of fish spawning and intense feeding (Filipović Marijić and Raspor 2010). Iron and $\mathrm{Mn}$ were $80-90 \%$ higher during the spawning period, while $\mathrm{Cu}, \mathrm{Zn}$ and $\mathrm{Cd}$ from $20-30 \%$. The variability of the gastrointestinal cytosolic metal concentrations between spawning (April/May) and post-spawning period (September), might reflect differences in fish nutritional processes, which arise due to increased water temperature, food availability and reproduction related physiological changes in April/May period (Clements and Raubenheimer 2006). As already stated, it can be supported by higher Fulton condition indices, in the chub sampled in April/May (Tables 2 and 3), which reflect the energy reserves and give the information about the recent feeding activity (Lambert and Dutil 1997).

Seasonal differences were also reflected in different spatial distribution of metal levels in gastrointestinal cytosolic fraction in two samplings. In the spring spawning period, higher $\mathrm{Zn}, \mathrm{Fe}$ and $\mathrm{Mn}$ levels were found at two upstream locations compared to three downstream locations, and the difference was statistically significant for Fe and Mn (Fig. 8e,g,i). As stated in the section 4.1., several chub individuals might be considered as sexually mature based on the increased GSIs in the spring period, which was especially evident at the upstream sites and which might have caused increased levels of these essential metals associated to gonad development. Copper levels were slightly increased at Otok Samoborski and Lukavec Posavski (Fig. 8c), while Cd levels were the lowest at Jasenovac and comparable at other four locations (Fig. 8a). Under the conditions of low metal contamination of the river water, metal levels tend to show significant relationship with biotic factors. Such association was evident between metals in the chub gastrointestinal cytosol and hepatosomatic index. Positive association with hepatosomatic index was statistically significant for $\mathrm{Fe}$ and $\mathrm{Mn}$ in gastrointestinal 
cytosol ( $\mathrm{r}=0.32, \mathrm{p}<0.01$ and $\mathrm{r}=0.41, \mathrm{p}<0.01$, respectively). In addition, as seen from Table 2, enhanced fish nutrition (higher condition and hepatosomatic indices) was specific for April/May, the period characterized by chub spawning and presumably increased feeding rate and metabolic activity. Therefore, different feeding rates, metabolic activity and spawning related changes in fish might have influenced spatial distribution of gastrointestinal metal concentrations in April/May campaign.

In September, spatial metal distribution followed different pattern. Cadmium and $\mathrm{Cu}$ tended to increase towards the downstream locations (Fig. 8b,d), while $\mathrm{Fe}$ and $\mathrm{Zn}$ were significantly higher at Oborovo compared to the remaining sites (Fig. 8f,j). Manganese concentrations were the highest at Otok Samoborski and Jasenovac (Fig. 8h). Since dissolved metal concentrations in the Sava River water were low (section 2., Dragun et al. 2009c), evident increase of some metal concentrations towards the downstream locations might indicated that gastrointestinal metal levels reflected metal exposure from food, thus highlighting the importance of considering both waterborne and dietborne metal uptake. This statement could be further confirmed by spatial distribution of metal concentrations in the gut content, which was comparable to spatial distribution of gastrointestinal metal levels in the cytosolic fraction for all five measured metals in April/May and for $\mathrm{Cu}, \mathrm{Mn}$ and $\mathrm{Zn}$ in September (Filipović Marijić and Raspor 2012). Besides possible impacts of the industrial facilities at downstream sites, especially of the oilrefinery situated in the city of Sisak, possible impacts of biotic factors on metal levels were again analyzed for September campaign, especially having in mind that the oldest fish were found at downstream locations. The results of correlation analysis confirmed significant positive relationship with fish age for gastrointestinal cytosolic concentrations of $\mathrm{Mn}(\mathrm{r}=0.28, \mathrm{p}<0.05)$ and $\mathrm{Cd}(\mathrm{r}=0.46, \mathrm{p}<0.01)$. Accordingly, statistically significantly higher metal concentrations in the gastrointestinal cytosol of 4-5 year old chub compared to 1-2 year old individuals were obtained for $\mathrm{Cu}, \mathrm{Mn}$ and $\mathrm{Cd}$ (Mann-Whitney rank sum test, $\mathrm{p}<0.05$; Filipović Marijić and Raspor 2012). In addition to already reported age dependence of several elements in the liver, kidney or gill tissue of various freshwater fish (Farkas et al. 2003; Filipović Marijić and Raspor 2006; Dragun et al. 2007), our results confirmed that accumulation of $\mathrm{Mn}$ and $\mathrm{Cd}$ also occurs with age in the gastrointestinal cytosol of European chub. 

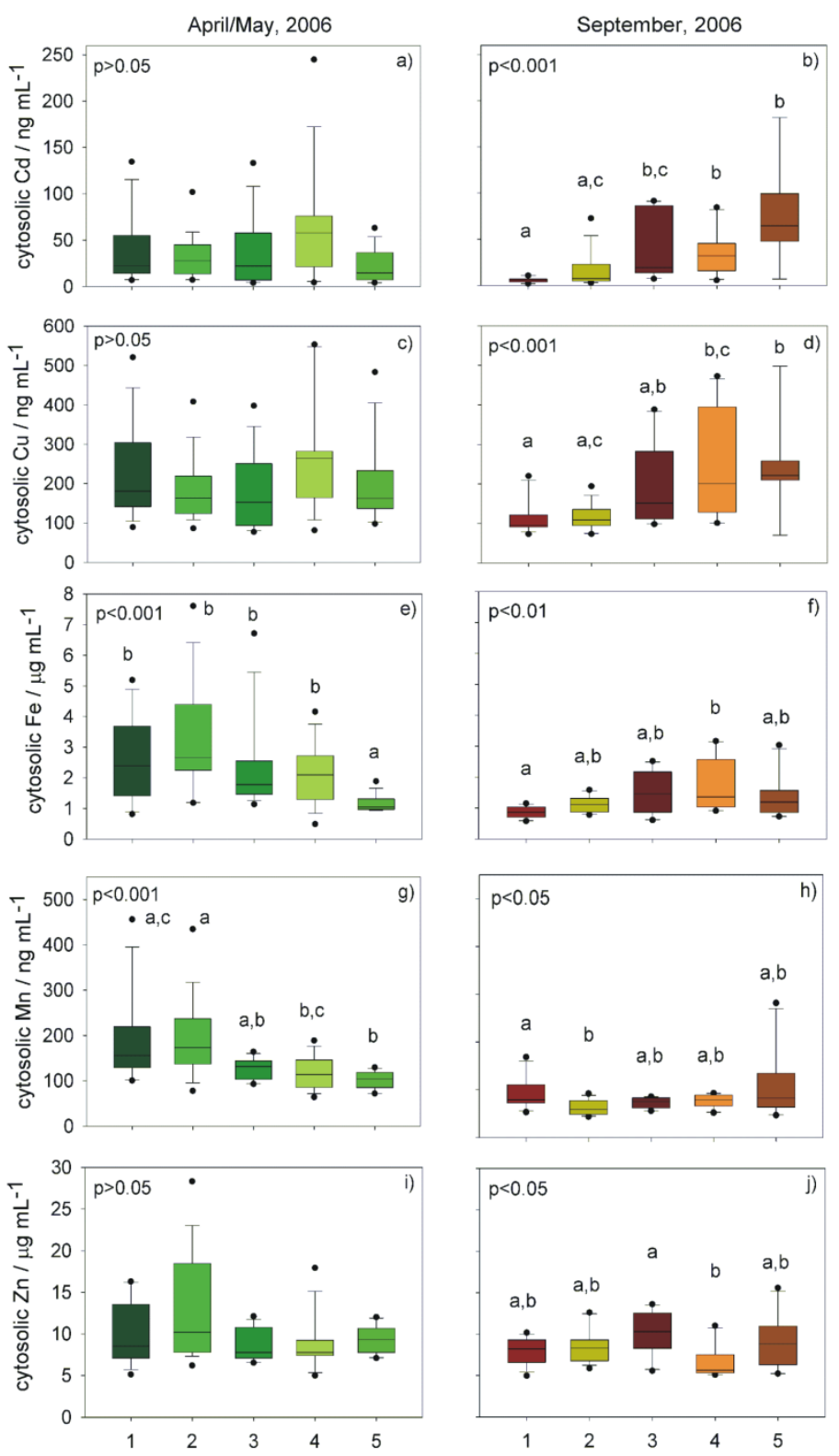

Figure 8. Spatial distribution of the concentrations of five trace elements in the gastrointestinal cytosol of chub caught in the Sava River in two periods, April/May and September 2006, at five sampling sites ( 1 - Otok Samoborski ( $\mathrm{n}=13$ and 15, respectively); 2 - Zagreb ( $\mathrm{n}=18$ and 14, respectively); 3 - Oborovo ( $\mathrm{n}=13$ and 10, respectively); 4 - Lukavec Posavski ( $\mathrm{n}=15$ and 10, respectively); 5 - Jasenovac 
$(\mathrm{n}=14$ and 10, respectively)). The results are presented same as indicated in the Fig. 3 .

\subsection{Comparison of metal bioaccumulation in three organs}

Various elements show tendency to accumulate in different fish organs, which can differ between sampling periods, but also can depend on the route of metal uptake (waterborne/dietborne) and on the level of metal exposure. At low level of metal exposure, such as observed in the Sava River, the following patterns of metal distribution between three chub organs were defined for constitutive metal levels:

$\mathrm{Cu}, \mathrm{Mn}$ (April/May and September):

liver $>$ gastrointestinal tissue $>$ gills

Zn (April/May):

$\mathrm{Zn}$ (September):

Fe (April/May and September):

Cd (April/May and September):

gills $>$ gastrointestinal tissue $>$ liver gastrointestinal tissue $>$ gills $>$ liver gills $>$ liver $>$ gastrointestinal tissue gastrointestinal tissue $>$ liver $>$ gills

Tendency to accumulate in the liver was observed for $\mathrm{Cu}$ and $\mathrm{Mn}$, whereas opposite trend was observed for $\mathrm{Zn}$ with the lowest accumulation in the liver, in both April/May and September sampling. High tendency of $\mathrm{Zn}$ to accumulate in the gastrointestinal tissue is consistent with the previous finding that intestine serves as Zn storage tissue in fish (Sun and Jeng 1998). The highest Fe levels were measured in the gills, probably in association with Fe being an integral part of the oxygen binding metalloprotein haemoglobin (Bury et al. 2012), since gills are richly supplied with blood vessels in order to act as a respiratory organ. The highest accumulation of $\mathrm{Cd}$ was observed in the gastrointestinal tissue, thus implying the predominant uptake from the food sources, which is consistent with previous reports on prevailing dietary metal uptake in the water with low metal levels (Dallinger and Kautzky 1985). The difference in metal concentrations between three organs was especially evident for $\mathrm{Cu}$. The hepatic $\mathrm{Cu}$ levels were on average 6-15 times higher compared to gastrointestinal tissue and gills in the spring, and as much as 10-40 times in September. Contrary, the differences between the concentrations in different chub organs for other metals were much less pronounced.

In addition to the selection of the most appropriate organ which shows the highest tendency for specific metal accumulation, it is also important to keep in mind that metal accumulation depends on many other factors, such as the time of sampling, physiological variability, as well as the route of metal uptake. It was observed that seasonal variability of metal accumulation was mostly governed by the reproduction related processes, such as gonad development, as well as concurrent increase in the water filtration and feeding rate in the spring period due to higher requirements for nutrients. Accordingly, due to the function of essential metals in the metabolic processes during the spawning period, their concentrations were increased in all three organs in the spring, and in the uptake organs (gills and intestine) even the concentrations of nonessential metal $\mathrm{Cd}$. 
The spatial distribution of metal concentrations in the chub organs was also influenced by the reproductive cycle. The association with gonadosomatic index, hepatosomatic index and the sexual maturity of fish was observed in the spring period for essential elements in both liver and the intestine, which is the reason why the post-spawning period was recommended as more appropriate for the assessment of chub metal exposure by use of these two organs. Contrary, the spring period seems more adequate for the assessment of metal exposure if the gills are applied as target organ, due to higher uptake of metals as a consequence of higher rate of water filtration. Finally, when evaluating chub metal exposure using any of these three organs, the chub age also has to be considered, since several elements exhibit tendency to accumulate with age.

\section{Metal bioaccumulation in the chub intestinal parasites acanthocephalans}

In the past decades, the interrelation between parasites and contaminants has gained increasing interest, especially in aquatic ecotoxicology (Sures 2001 and 2003). Certain parasites, particularly intestinal acanthocephalans of fish, have enormous accumulation capacity for metals, especially toxic ones and can respond very rapidly to changes in the environmental exposure (Sures 2003). Accordingly, attempts were made at using acanthocephalans as biological indicators of metal exposure in the environmental risk assessment studies (Sures et al. 1999a). Till now, most of the papers indicated that metal accumulation in the parasites is more effective than in the tissues of their hosts or commonly used indicator organisms. Application of acanthocephalans as biological indicators in metal exposure assessment of the Sava River involved comparison of metal concentrations and their spatial distribution in two acanthocephalan species, Pomohorhynchus laevis and Acanthocephalus anguillae, and their host, European chub (Fig. 9). For the purposes of direct comparison of metal concentrations in the fish and acanthocephalans, essential (Fe, $\mathrm{Zn}, \mathrm{Mn}, \mathrm{Cu})$ and nonessential $(\mathrm{Cd})$ trace metals were not only measured in the fish gastrointestinal cytosol, but additionally in the gastrointestinal tissue.

Basic epidemiological characteristics of acanthocephalans from the chub sampled along the Sava River are shown in Table 4. In both sampling periods, higher intensity of infection was found for P. laevis than for A. anguillae. Moreover, $P$. laevis individuals were predominant in female chub in both seasons, while $A$. anguillae only in April/May. Seasonal differences were evident in mean intensity of infection, which was higher in the spring for both acanthocephalan species. 


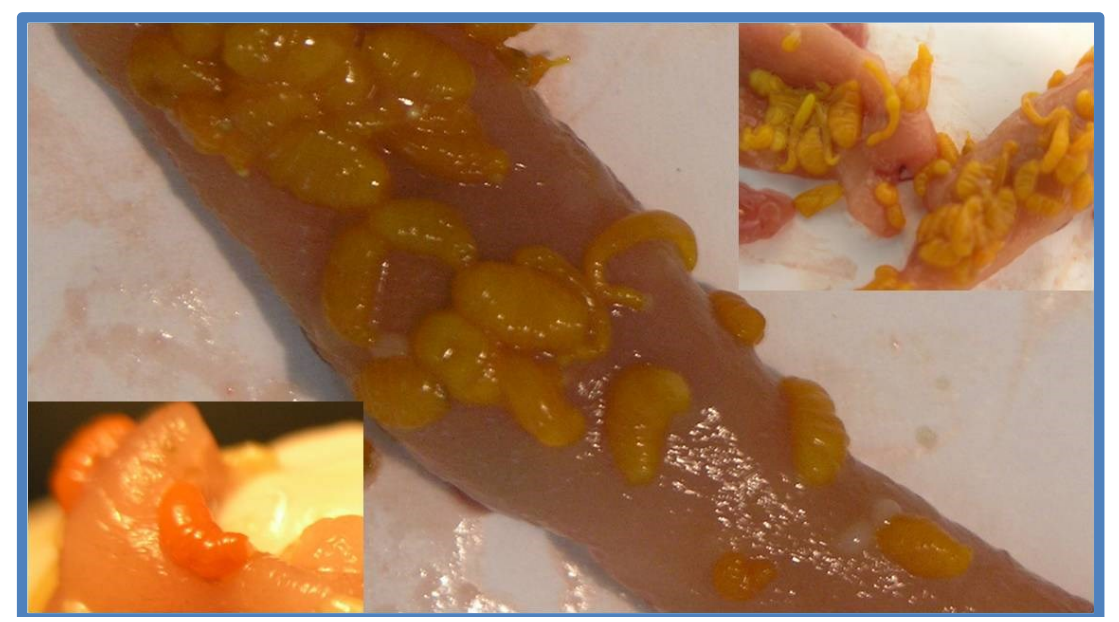

Figure 9. Acanthocephalans, the intestinal parasites of European chub (Squalius cephalus L.) from the Sava River.

Table 4. Basic epidemiological characteristics of acanthocephalans from the chub sampled along the Sava River: number and percentage of uninfected chub, prevalence of infection for each parasite (number and percentage of infected chub), mean intensity of infection, and total number of parasite individuals in sampled chub (in males and females).

\begin{tabular}{|c|c|c|c|c|c|c|c|}
\hline \multirow{2}{*}{$\begin{array}{c}\text { Sampling } \\
\text { period } \\
n \\
\text { (number of } \\
\delta / O / \text { ND) }\end{array}$} & \multirow{2}{*}{$\begin{array}{l}\text { Uninfected } \\
\text { chub / } \\
n \\
(\%)\end{array}$} & \multicolumn{2}{|c|}{$\begin{array}{c}\text { Prevalence / } \\
\mathrm{n} \\
(\%)\end{array}$} & \multicolumn{2}{|c|}{$\begin{array}{c}\text { Mean } \\
\text { intensity of } \\
\text { infection }\end{array}$} & \multicolumn{2}{|c|}{$\begin{array}{c}\text { Total number } \\
n \\
(\delta / O) \\
\end{array}$} \\
\hline & & PL & AA & PL & $\mathrm{AA}$ & PL & AA \\
\hline $\begin{array}{c}\text { April/May } \\
n=76 \\
(30 / 46 / 0)\end{array}$ & $\begin{array}{c}20 \\
(26 \%)\end{array}$ & $\begin{array}{c}40 \\
(53 \%)\end{array}$ & $\begin{array}{c}36 \\
(47 \%)\end{array}$ & 4.2 & 3.3 & $\begin{array}{c}167 \\
(53 / 114)\end{array}$ & $\begin{array}{c}120 \\
(36 / 84)\end{array}$ \\
\hline $\begin{array}{l}\text { September } \\
n=59 \\
(18 / 36 / 5)\end{array}$ & $\begin{array}{c}25 \\
(42 \%)\end{array}$ & $\begin{array}{c}31 \\
(53 \%)\end{array}$ & $\begin{array}{c}11 \\
(19 \%)\end{array}$ & 3.0 & 1.4 & $\begin{array}{c}93 \\
(14 / 79)\end{array}$ & $\begin{array}{c}15 \\
(5 / 10)\end{array}$ \\
\hline
\end{tabular}

$\mathrm{n}$ - number of fish; ND - not determined; PL - P. laevis; AA - A. anguillae

Total number - total number of parasite individuals in the sampled chub

\subsection{Metal concentrations in the chub gastrointestinal tissue and acanthocephalans}

In both seasons, concentrations of $\mathrm{Cu}, \mathrm{Mn}$ and $\mathrm{Cd}$ in acanthocephalans were significantly higher than in the chub gastrointestinal tissue, while $\mathrm{Zn}$ and $\mathrm{Fe}$ levels were significantly higher in the chub gastrointestinal tissue, with exception 
of comparable Fe levels in A. anguillae and chub gastrointestinal tissue in September (Fig. 10).
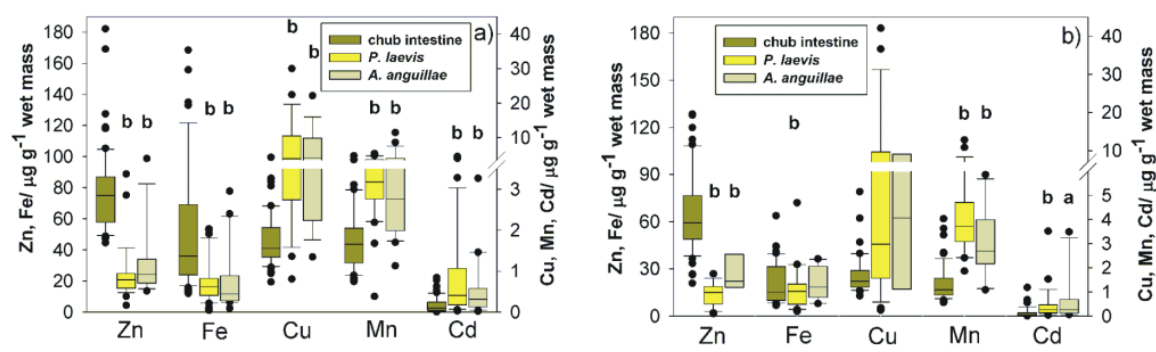

Figure 10. Metal levels ( $\mu \mathrm{g} \mathrm{g}^{-1}$ wet mass) in the chub gastrointestinal tissue, Pomphorhynchus laevis and Acanthocephalus anguillae in a) April/May and b) September. The results are presented same as indicated in the Fig. 3. Statistically significant differences (Mann-Whitney rank sum test) in metal levels between chub gastrointestinal tissue and parasites at the significance level $p<0.01$ (a) and $p<0.001$ (b) are indicated.

The most pronounced difference between metal concentrations in the intestinal parasites and the gastrointestinal tissue of the chub from the Sava River was evident for $\mathrm{Cu}$ and $\mathrm{Cd}$, which levels were from 3-5 times higher in acanthocephalans than in their host in both seasons. One of the possible explanations of higher metal concentrations in acanthocephalans than in the fish tissues is based on parasite dependence on host micronutrients, since they lack gastrointestinal system. Essential metals, as elements of physiological importance, are highly absorbed from fish intestine by acanthocephalans. It is therefore possible that competition among parasites for essential elements, may also lead to the increased absorption of nonessential elements, such as Cd (Sures 2002).

Parallel analysis of metal concentrations in the intestinal parasites and their host represents a combination of short time and long time exposure, since acanthocephalan life span is relatively short and ranges from 50-140 days (Keneddy 1985), compared to much longer chub life span, which ranges from 10-15 years (Kottelat and Freyhof 2007). Therefore, the ratio between metal concentrations in the acanthocephalans and the host tissue, which is named bioconcentration factor, could provide information on the duration of environmental exposure, as metal uptake occurs more rapidly in the parasites. Low ratio, i.e. comparably high metal levels in both fish parasites and intestine, would indicate a longer exposure time compared to high ratio, i.e. higher metal levels in the parasites than in the intestine (Siddall and Sures 1998). The highest bioconcentration factors in the chub intestinal parasites were found for $\mathrm{Cd}$ and $\mathrm{Cu}$, which ranged from 3.3-5.1 in both sampling seasons, followed by $\mathrm{Mn}(2-3), \mathrm{Fe}(0.4-1)$ and $\mathrm{Zn}(0.2-0.4)$. Compared to our study, bioconcentration factors previously calculated as the ratio between metal concentrations in Acanthocephalus lucii and perch intestine were higher for $\mathrm{Cu}(50)$, 
Cd (20), Fe (6), and Zn (8) and comparable for Mn (2) (Sures et al. 1999b). Data related to $P$. laevis-barbel system also reported higher bioconcetration factors compared to our study, for example for $\mathrm{Cd}$ (15.6), $\mathrm{Cu}$ (11.0), $\mathrm{Zn}$ (4.0) and $\mathrm{Mn}$ (3.9) between $P$. laevis and intestinal tissue of barbel from the Danube River in Bulgaria (Nachev et al. 2013), and for Cd (15.6), Cu (11.0), Zn (4.0) and Mn (3.9) between $P$. laevis and intestinal tissue of barbel from the Danube River in Hungary (Thielen et al. 2004). Therefore, lower bioconcentration factors in both acanthocephalan species from chub compared to the other studies indicated that acute metal exposure did not occur in the Sava River. This finding is supported by the results on average total dissolved metal concentrations in the surface water of the Sava River, which were not significantly above the natural level (section 2., Dragun et al. 2009c).

5.2. The comparison of spatial metal distribution in the chub gastrointestinal tissue and acanthocephalans

In order to evaluate the application of acanthocephalans as bioindicators of metal exposure in the Sava River, spatial metal distribution in the parasites and chub hosts was compared. Due to the influences of the fish spawning and higher feeding intensity in the spring period on the gastrointestinal cytosolic metal concentrations in fish dwelling in the low metal contaminated river water, site specific differences of metal levels were considered only for the post-spawning season, in September (Fig. 11). In addition, metal concentrations in the gastrointestinal tissues of uninfected chub and chub infected with $P$. laevis were compared, since it was reported that acanthocephalans might alter metal uptake and accumulation, resulting in reduced metal levels in tissues of infected host (Sures 2008). Only the data for $P$. laevis were presented since the total number of $A$. anguillae at five sampling locations was too low to allow statistical treatment (1-7 individuals per location). 

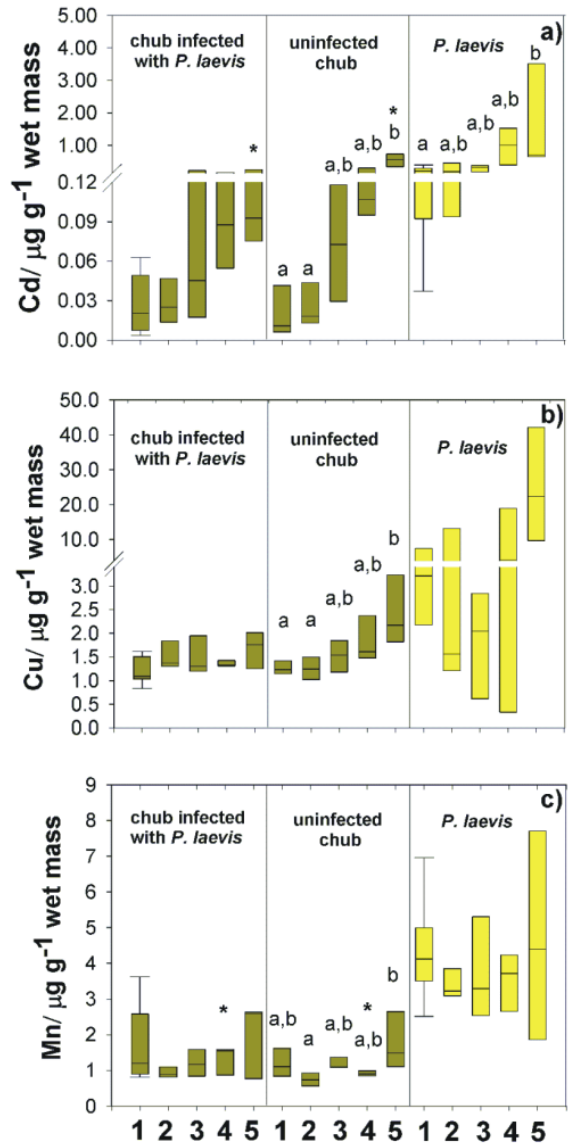

Figure 11. Spatial distribution of a) $\mathrm{Cd}, \mathrm{b}) \mathrm{Cu}$ and c) $\mathrm{Mn}$ levels ( $\mu \mathrm{g} \mathrm{g}^{-1}$ wet mass) in $P$. laevis and gastrointestinal tissue of uninfected chub and chub infected with $P$. laevis. The number of analyzed samples per site was $9 / 7 / 4 / 3 / 3$ for infected chub, 5/4/4/7/5 for uninfected chub, and 15/8/6/4/3 for $P$. laevis. The results are presented same as indicated in the Fig. 3. Statistically significant differences at the significance level $p<0.05$ among different locations are indicated with different letters (Kruskal Wallis one way analysis of variance with Dunn's test for allpairwise comparisons) and between uninfected and infected group of chub from the same location by asterisk ( $<<0.05$, Mann-Whitney rank sum test).

In Fig. 11., only spatial distribution of metals with higher accumulation in parasites than chub gastrointestinal tissue was presented, i.e. $\mathrm{Cu}, \mathrm{Mn}$ and $\mathrm{Cd}$. All three metals showed the same spatial pattern in P. laevis and gastrointestinal tissue of uninfected and infected chub. Concentrations of these metals were increased towards the downstream locations, with statistically significant difference between upstream and downstream locations for $\mathrm{Cu}$ and $\mathrm{Cd}$ in uninfected chub and $\mathrm{Cd}$ in $P$. 
laevis. Spearman correlation analysis confirmed significant relationship of $\mathrm{Cd}$ $(\mathrm{r}=0.75, \mathrm{p}<0.01)$ in the chub gastrointestinal tissue and P. laevis. Increased $\mathrm{Cd}$ concentrations towards the downstream locations were also evident in the cytosolic fractions of the chub liver (Fig. 6b), gills (Fig. 7b) and gastrointestinal tissue (Fig. $8 \mathrm{~b}$ ), and of $\mathrm{Cu}$ and $\mathrm{Mn}$ in the chub gastrointestinal tissue (Fig. 8d,h). Therefore, our data indicate $P$. laevis as promising biological indicator of bioavailable metal concentrations. It is evident that site-specific differences were more pronounced in uninfected chub for $\mathrm{Cu}$ and $\mathrm{Cd}$, which levels were 6.0 and 1.5 times, respectively, higher than in the chub infected with $P$. laevis. Previous studies revealed that acanthocephalans can reduce metal levels in the tissues of their hosts (Sures and Siddall 1999; Sures 2008). Bile-metal complexes formed in the fish liver pass down the bile duct into the small intestine, where in the infected fish acanthocephalans take up bile-bound metals and reduce the amount of metals available for reabsorption by the host. In uninfected fish bile-bound metals can either be reabsorbed by the intestinal wall or, to a lesser extent, excreted with the faeces (Sures and Siddall 1999). Our results indicate that even in the river water with the low metal contamination, $P$. laevis reduced $\mathrm{Cu}$ and $\mathrm{Cd}$ levels in the chub gastrointestinal tissue and, therefore, parasites should be taken into account as a potential confounding factor in the environmental risk assessment studies.

\section{Metallothionein - biomarker of metal exposure}

Metallothioneins (MTs) constitute a family of low-molecular, cysteinerich proteins functioning in the regulation of the essential metals $\mathrm{Cu}$ and $\mathrm{Zn}$, as well as in detoxification of both essential metals excessively present in the cells and nonessential metals with no known biological functions, such as $\mathrm{Cd}, \mathrm{Hg}$, and $\mathrm{Ag}$ (Olsson et al. 1998). Induction of MT synthesis is one of the best known biochemical responses to increased bioavailability of metals in the environment and, therefore, it is applied as a biomarker of metal exposure (Amiard et al. 2006; Olsson et al. 1998). The binding of metals to MT has a sequestration function that renders them unable to interact with other sensitive molecules and, thereby, produces protection against metal toxicity at the cellular level (Kay et al. 1986; Roesijadi 1992).

MT concentrations in the liver, gills and gastrointestinal tissue were used to evaluate biochemical response to metal exposure in the chub from the Sava River. Many factors unrelated to metal contamination can also induce MT synthesis and their influence on MT level should also be considered and estimated (Hylland et al. 1998; Gorbi et al. 2005). Therefore, next to the assessment of the spatial variation of MTs as a result of different metal exposure, MT levels were also compared between two sampling seasons, to observe their possible association with fish spawning and concurrent physiological changes. 


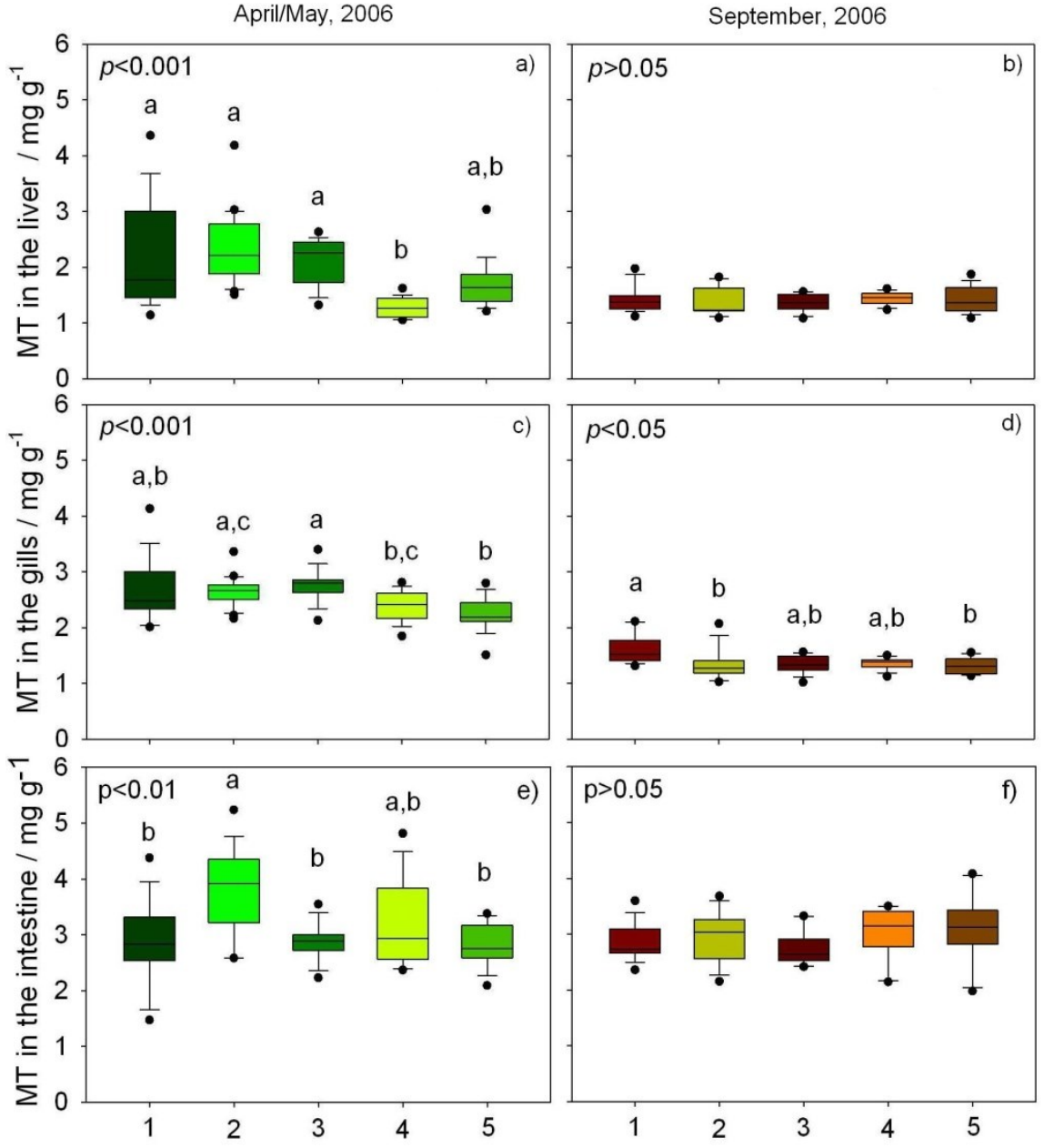

Figure 12. Spatial distribution of metallothionein (MT) concentrations in the liver, gills and gastrointestinal tissue of chub caught in the Sava River in two periods, April/May and September 2006, at five sampling sites. The number of analyzed samples per site was 13/17/11/15/14 in April/May and 15/7/7/8/10 in September for hepatic MT, 15/18/12/15/14 in April/May and 13/14/10/10/10 in September for gill MT, and 14/18/13/15/14 in April/May and 15/14/10/10/10 in September for gastrointestinal MT. The results are presented same as indicated in the Fig. 3.

Since MTs present heat stable proteins, their measurement was performed in the heat-treated cytosolic fraction, which was obtained after the heat-treatment at $85^{\circ} \mathrm{C}$ for 10 minutes (Erk et al. 2002). MT analyses were performed by differential pulse voltammetry on 797 Computrace (Metrohm, Switzerland), according to the modified Brdička procedure (Raspor et al. 2001). MTs were quantified from the 
calibration straight line using commercially available $>95 \%$-pure zinc-MT (I+II) from rabbit liver (MT-95-P, Ikzus Proteomics), dissolved in $0.25 \mathrm{M} \mathrm{NaCl}$.

The comparison of MT concentrations in three chub organs indicated that MTs were always present in the highest concentrations in the gastrointestinal tissue, then in the gills, and the lowest in the liver. Since gill and gastrointestinal epithelial tissues are involved in the uptake, detoxification and excretion processes (Van Cleef et al. 2000), higher MT presence in those tissues is probably associated with the important function of MTs in metal uptake, as well as their protective role against excessive uptake.

However, the concentrations in the gills exhibited the strongest seasonal dependence, with the spring concentrations being almost two times higher than in September $(p<0.001$; Mann-Whitney rank sum test; Dragun et al. 2009b). Gastrointestinal MT concentrations were comparable in both sampling periods ( $p>0.05$; Filipović Marijić and Raspor 2010), whereas hepatic MT was higher in the spring ( $p<0.001$; Podrug and Raspor 2009), but the difference was less pronounced than in the gills. Therefore, gill MT concentrations were close to high levels of gastrointestinal MTs in the spring period, and decreased to lower hepatic MT value in September sampling (Fig. 12). The spring increase of metal and MT concentrations in the gills could be explained as a consequence of increased metabolic and feeding activity (Dragun et al. 2007). Enhanced feeding was previously suggested as a possible influential factor on MT level (George and Olsson 1994; McCoy et al. 1995), and it was confirmed in the spring period by significantly higher Fulton condition indices compared to autumn season (Table 2 and 3; Dragun et al. 2007). It could have caused metabolic stimulation, which subsequently causes accelerated gill ventilation, and thereby also the enhanced uptake of essential, as well as toxic metals (Chovanec et al. 2003). It is, therefore, possible that pronounced spring increase of MT level in the gills was an outcome of its important role in uptake of essential metals, such as Zn (Bury et al. 2003). The seasonal variability of the hepatic MT was, on the other hand, attributed to different phases of the reproductive cycle, with higher levels obtained in the prespawning/spawning period due to the process of vitellogenesis (Podrug and Raspor 2009). Less pronounced seasonal difference of hepatic MT compared to gill MT could be explained by the fact that chub in this study were mainly not sexually mature.

Although MT is a biomarker of metal exposure, any factor which is able to influence protein metabolism will be also able to influence MTs directly, whereas factors known to influence metal uptake and accumulation, such as size, sex or sexual maturity, will be able to influence MTs indirectly (Amiard et al. 2006). For example, female chub had somewhat higher average hepatic MT level in the reproductive period $\left(2.01 \mathrm{mg} \mathrm{g}^{-1}\right)$ than males $\left(1.82 \mathrm{mg} \mathrm{g}^{-1}\right.$; Podrug and Raspor 2009), while there was no difference between sexes in the gill MT level (Dragun et al. 2009b). The sex differences were probably more evident in the liver than gill tissue, because liver has an important role in the reproduction, for example in the process of vitellogenesis (Werner et al. 2003). In addition, the estimation of gender 
related differences in the gastrointestinal tissue indicated significantly higher MT levels in males in April/May than in September ( $p<0.5$, Mann-Whitney rank sum test), probably because the sampled chub population in April/May comprised few sexually mature males from the upstream sites (Filipović Marijić and Raspor 2010).

Gill MT levels in the spring period, on the other hand, varied depending on the chub age and mass. Approximately 10\% higher MT levels were obtained in the gills of younger fish $(p<0.05)$, and accordingly correlation between mass and gill MT level was negative. Younger and smaller fish are known to have faster filtration and metabolic rates, and consequently higher concentrations of proteins (e.g. metallothioneins) in fish tissues can be expected as the result of homeostatic regulation (Wiener and Giesy 1979), especially in the period of more intense metabolic activity, such as presumably spring reproductive period (Dragun et al. 2009b).Contrary, in September sampling campaign, positive association was obtained between MTs and the gill mass (Dragun et al. 2009b).

Physiological variability of MT levels has also reflected on the spatial distribution of this biomarker. In the spring period, increased MT concentrations in all three organs were found at upstream sites: in the liver and gills at the sites 1-3 (Otok Samoborski, Zagreb, Oborovo; Fig. 12a,c; Dragun et al. 2009b; Podrug and Raspor 2009), and in the gastrointestinal tissue only at the site 2 (Zagreb; Fig. 12e; Filipović Marijić and Raspor 2012). Increased MT levels coincided with increased cytosolic concentrations of essential elements: $\mathrm{Zn}$ and $\mathrm{Mn}$ in the liver (Podrug and Raspor 2009), $\mathrm{Zn}$ in the gills (Dragun et al. 2009b), and $\mathrm{Zn}, \mathrm{Fe}$ and $\mathrm{Mn}$ in the gastrointestinal tissue. Gastrointestinal MT additionally showed clear association with spatial distribution of HSI (Filipović Marijić and Raspor 2012). Although chub in this study were mainly not sexually mature, at upstream sampling sites several specimens had increased GSI in the spring period, indicated their sexual maturity. Therefore, the influence of fish spawning and concurrent increase of metabolic activity, feeding rate and water filtration was probably reflected in MT concentration increase in all three organs. In addition, association between spatial distribution of MT and Zn concentrations was characteristic for all three organs, which could be attributed to a significant role of MTs in both Zn homeostasis and detoxification. However, in our study, MT association with cytosolic $\mathrm{Zn}$ was more probably related to its function in $\mathrm{Zn}$ regulation, than to the level of exposure in the water, since $\mathrm{Zn}$ concentrations in the Sava River water were exceptionally low $(<5$ $\mu \mathrm{g} \mathrm{L}^{-1}$; Dragun et al. 2009c).

In September campaign, MTs generally showed less variability between sites in all three organs (Fig. 12b,d,f), and only significant differences were observed in the gills (Fig. 12d), with the highest MT level measured at the sampling site 1 (Otok Samoborski). Spatial distribution of gill MTs was similar to Fulton condition indices and the gill masses, indicating to strong MT association with the chub size and condition (Dragun et al. 2009b). Although in September Cd, $\mathrm{Cu}$ and $\mathrm{Fe}$ in the gill cytosol, and $\mathrm{Cd}$ and $\mathrm{Cu}$ levels in the gastrointestinal and hepatic cytosol, as well as in P. laevis, showed increasing trend towards the downstream 
locations, accumulated metal levels were probably not high enough to induce additional MT synthesis and to show significant association with MTs.

Since metal exposure in the Sava River water was defined as low and comparable to natural conditions (Dragun et al. 2008 and 2009c) and the variability of MT concentrations in all three organs was predominantly associated to reproduction- and nutrition-related changes (Dragun et al. 2009b; Podrug and Raspor 2009; Filipović Marijić and Raspor 2012), the constitutive MT levels were defined for each organ, separately for the spawning and post-spawning periods, as mean \pm one standard deviation (encompassing $68 \%$ of the obtained data). Constitutive MT concentrations in the gastrointestinal tissue were similar in the spawning and post spawning period, 2.4-3.9 $\mathrm{mg} \mathrm{g}^{-1}$ and $2.5-3.4 \mathrm{mg} \mathrm{g}^{-1}$, respectively. Contrary, constitutive gill and hepatic MT concentrations were higher in the spawning period (2.1-3.0 $\mathrm{mg} \mathrm{g}^{-1}$ and $1.2-2.7 \mathrm{mg} \mathrm{g}^{-1}$, respectively) compared to the post-spawning period (1.2-1.7 mg g${ }^{-1}$ and $1.2-1.6 \mathrm{mg} \mathrm{g}^{-1}$, respectively). At low level of dissolved metals in the river water, MTs in the chub organs reflected physiological changes to a greater extent than metal exposure from the river water. 


\section{References}

Amiard J-C, Amiard-Triquet C, Barka S, Pellerin J, Rainbow PS (2006) Metallothioneins in aquatic invertebrates: Their role in metal detoxification and their use as biomarkers. Aquat Toxicol 76:160-202

Andres S, Ribeyre F, Tourencq J-N, Boudou A (2000) Interspecific comparison of cadmium and zinc contamination in the organs of four fish species along a polymetallic pollution gradient (Lot River, France). Sci Total Environ 248:1125

Bury NR, Walker PA, Glover CN (2003) Nutritive metal uptake in teleost fish. J Exp Biol 206:11-23

Bury NR, Boyle D, Cooper CA (2012) Iron. In: Wood CM, Farrell AP, Brauner CJ (eds) Fish physiology: Homeostasis and toxicology of essential metals, vol. 31A. Academic, London

Campbell PGC (1995) Interactions between trace metals and aquatic organisms: a critique of the free-ion activity model. In: Tessier A, Turner DR (eds) Metal speciation and bioavailability in aquatic systems. IUPAC, John Wiley and Sons Ltd., New York

Chovanec A, Hofer R, Schiemer F (2003) Fish as bioindicators. In: Markert BA, Breure AM, Zechmeister HG (eds) Bioindicators and biomonitors: Principles, concepts and applications. Elsevier Science Ltd., Amsterdam

Clearwater SJ, Baskin SJ, Wood CM, McDonald DG (2000) Gastrointestinal uptake and distribution of copper in rainbow trout. J Exp Biol 203:2455-2466

Clements KD, Raubenheimer D (2006) Feeding and nutrition. In: Evans DH, Claiborne JB (eds) The physiology of fishes. CRC Press, Boca Raton

Dallinger R, Kautzky H (1985) The importance of contaminated food and uptake of heavy metals by rainbow trout (Salmo gairdneri): a field study. Oecologia 67:82-89

Dautović J (2006) Metal determination in natural waters using high resolution inductively coupled plasma mass spectrometry (in Croatian). B.Sc. Thesis, Faculty of Science, University of Zagreb

Dautović J, Roje V, Kozar S, Fiket Ž, Mikac N (2007) Dissolved trace metals in some rivers and lakes from the Republic of Croatia (in Croatian). In: Croatian waters and European Union - challenges and potentials, Proceedings of $4^{\text {th }}$ Croatian conference on waters, with international participation, Opatija

Davison W, Zhang H (1994) In situ speciation measurements of trace components in natural waters using thin-film gels. Nature 367:546-547

Davison W, Zhang H (2002) In situ measurement of labile species in water and sediments using DGT. In: Varney MS (ed) Chemical sensors in oceanography. Taylor \& Francis Group

Dragun Z, Raspor B, Podrug M (2007) The influence of the season and the biotic factors on the cytosolic metal concentrations in the gills of the European chub (Leuciscus cephalus L.). Chemosphere 69:911-919

Dragun Z, Raspor B, Roje V (2008) The labile metal concentrations in Sava River water assessed by diffusive gradients in thin films. Chem Spec Bioavailab 20:33-46 
Dragun Z, Podrug M, Raspor B (2009a) Combined use of bioindicators and passive samplers for the assessment of river water contamination with metals. Arch Environ Con Tox 57:211-220

Dragun Z, Podrug M, Raspor B (2009b) The assessment of natural causes of metallothionein variability in the gills of European chub (Squalius cephalus L.). Comp Biochem Phys C 150:209-217

Dragun Z, Roje V, Mikac N, Raspor B (2009c) Preliminary assessment of total dissolved trace metal concentrations in Sava River water. Environ Monit Assess 159:99-110

Dragun Z, Krasnići N, Strižak Ž, Raspor B (2012) Lead concentration increase in the hepatic and gill soluble fractions of European chub (Squalius cephalus) an indicator of increased $\mathrm{Pb}$ exposure from the river water. Environ Sci Pollut R 19:2088-2095

Elbaz-Poulichet F, Guan DM, Martin J-M (1991) Trace metal behaviour in a highly stratified Mediterranean estuary: The Krka (Yugoslavia). Mar Chem 32:211224

Elbaz-Poulichet F, Seidel J-L, Casiot C, Tusseau-Vuillemin M-H (2006) Short-term variability of dissolved trace element concentrations in the Marne and Seine Rivers near Paris. Sci Total Environ 367:278-287

Encina L, Granado-Lorencio C (1997) Seasonal variations in the physiological status and energy content of somatic and reproductive tissues of chub. J Fish Biol 50:511-522

Erk M, Ivanković D, Raspor B, Pavičić J (2002) Evaluation of different purification procedures for the electrochemical quantification of mussel metallothioneins. Talanta 57:1211-1218

European Parliament and the Council of the European Union (EPCEU) (2008) Directive 2008/105/EC of the European Parliament and of the Council on environmental quality standards in the field of water policy, amending and subsequently repealing Council Directives 82/176/EEC, 83/513/EEC, 84/156/EEC, 84/491/EEC, 86/280/EEC, and amending Directive 2000/60/EC of the European Parliament and of the Council. Official J L 348/84

Farkas A, Salánki J, Specziár A (2002) Relation between growth and the heavy metal concentration in organs of bream Abramis brama L. populating Lake Balaton. Arch Environ Con Tox 43:236-243

Farkas A, Salánki J, Specziár A (2003) Age- and size-specific patterns of heavy metals in the organs of freshwater fish Abramis brama L. populating a lowcontaminated site. Water Res 37:959-964

Filipović Marijić V, Raspor B (2006) Age and tissue dependent metallothionein and cytosolic metal distribution in a native Mediterranean fish, Mullus barbatus, from the Eastern Adriatic Sea. Comp Biochem Phys C 143:382-387

Filipović Marijić V, Raspor B (2007) Metal exposure assessment in native fish, Mullus barbatus L., from the Eastern Adriatic Sea. Toxicol Lett 168:292-301

Filipović Marijić V, Raspor B (2008) Hepatic metallothionein and metal (Zn, Cu and $\mathrm{Cd}$ ) variability in relation to reproductive cycle of Mullus barbatus and Merluccius merluccius from the Eastern Adriatic Sea. Fresen Environ Bull $17: 705-712$ 
Filipović Marijić V, Raspor B (2010) The impact of fish spawning on metal and protein levels in gastrointestinal cytosol of indigenous European chub. Comp Biochem Phys C 152:133-138

Filipović Marijić V, Raspor B (2012) Site-specific gastrointestinal metal variability in relation to the gut content and fish age of indigenous European chub from the Sava River. Water Air Soil Poll 223:4769-4783

Foulkes EC (2000) Transport of toxic heavy metals across cell membranes. P Soc Exp Biol Med 223:234-240

Gandolfi G, Zerunian S, Torricelli P, Marconato A (1991) I pesci delle acque interne italiane. Istituto Poligrafico e Zecca dello Stato, Rome.

Garofalo E., Ceradini S, Winter M (2004) The use of diffusive gradients in thinfilm (DGT) passive samplers for the measurement of bioavailable metals in river water. Ann Chim-Rome 94:515-520

George SG, Olsson P-E (1994) Metallothioneins as indicators of trace metal pollution. In: Kramer KJM (ed) Biomonitoring of coastal waters and estuaries. CRC Press, Boca Raton

Giguère A, Campbell PGC, Hare L, McDonald DG, Rasmussen JB (2004) Influence of lake chemistry and fish age on $\mathrm{Cd}, \mathrm{Cu}$ and $\mathrm{Zn}$ concentrations in various organs of indigenous yellow perch (Perca flavescens). Can J Fish Aquat Sci 61:1702-1716

Gimpel J, Zhang H, Hutchinson W, Davison W (2001) Effect of solution composition, flow and deployment time on the measurement of trace metals by the diffusive gradient in thin films technique. Anal Chim Acta 448:93-103

Gorbi S, Baldini C, Regoli F (2005) Seasonal variability of metallothioneins, cytochrome P450, bile metabolites and oxyradical metabolism in the European eel Anguilla anguilla L. (Anguillidae) and striped mullet Mugil cephalus L. (Mugilidae). Arch Environ Con Tox 49:62-70

Habeković D, Aničić I, Safner R (1993) Dinamika rasta klena u rijeci Savi. Ihtiofauna dijela rijeke Save. Croat J Fish 48:79-88

Harrison RM (1995) Understanding our environment: An introduction to environmental chemistry and pollution. The Royal Society of Chemistry, London.

Has-Schön E, Bogut I, Strelec I (2006) Heavy metal profile in five fish species included in human diet, domiciled in the end flow of river Neretva (Croatia). Arch Environ Con Tox 50:545-551

Heath AG (1995) Water pollution and fish physiology. Lewis Publishers, Boca Raton

Hylland K, Nissen-Lie T, Christensen PG, Sandvik M (1998) Natural modulation of hepatic metallothionein and cytochrome P4501 A in flounder, Platichthys flesus, L. Mar Environ Res 46:51-55

International Network for Acid Prevention (INAP) (2002) Diffusive gradients in thin-films (DGT): A technique for determining bioavailable metal concentrations.

http://www.inap.com.au/public downloads/Research Projects/Diffusive_Gra dients in Thin-films.pdf. Accessed 6 May 2013 
Karadede AH, Ünlü E (2007) Heavy metal concentrations in water, sediment, fish and some benthic organisms from Tigris River, Turkey. Environ Monit Assess 131:323-337

Kay J, Thomas DG, Brown MW, Cryer A, Shurben D, Solbe JF, Garvey JS (1986) Cadmium accumulation and protein binding patterns in tissues of the rainbow trout, Salmo gairdneri. Environ Health Perspect 65:133-139

Kennedy CR (2006) Ecology of the Acanthocephala. Cambridge University Press, Cambridge

Kottelat M, Freyhof J (2007) Handbook of European freshwater fishes. Kottelat, Cornol, Switzerland and Freyhof, Berlin

Koukal B, Dominik J, Vignati D, Arpagaus P, Santiago S, Ouddane B, Benaabidate L (2004) Assessment of water quality and toxicity of polluted Rivers Fez and Sebou in the region of Fez (Morocco). Environ Pollut 131:163-172

Kraemer LD, Campbell PGC, Hare L (2005) Dynamics of $\mathrm{Cd}, \mathrm{Cu}$ and $\mathrm{Zn}$ accumulation in organs and sub-cellular fractions in field transplanted juvenile yellow perch (Perca flavescens). Environ Pollut 138:324-337

Krča S, Žaja R, Čalić V, Terzić S, Grubešić MS, Ahel M, Smital T (2007) Hepatic biomarker responses to organic contaminants in feral chub (Leuciscus cephalus) - laboratory characterization and field study in the Sava River, Croatia. Environ Toxicol Chem 26:2620-2633

Lambert Y, Dutil J-D (1997) Can simple condition indices be used to monitor and quantify seasonal changes in the energy reserves of Atlantic cod (Gadus morhua)? Can J Fish Aquat Sci 54:104-112

Langston WJ, Spence SK (1995) Biological factors involved in metal concentrations observed in aquatic organisms. In: Tessier A, Turner DR (eds) Metal speciation and bioavailability in aquatic systems. John Wiley and Sons, Chichester

Maitland PS, Campbell RN (1992) Freshwater fishes of the British Isles. HarperCollins Publishers, London

McCoy CP, O'Hara TM, Bennett LW, Boyle CR, Lynn BC (1995) Liver and kidney concentrations of zinc, copper and cadmium in channel catfish (Ictalurus punctatus): variations due to size, season and health status. Vet Hum Toxicol 37:11-15

Mikac N, Branica M (1994) Input of ionic alkyllead compounds to surface waters. Sci Total Environ 154:39-46

Miramand P, Lafaurie M, Fowler SW, Lemaire P, Guary JC, Bentley D (1991) Reproductive cycle and heavy metals in the organs of red mullet, Mullus barbatus (L.), from the northwestern Mediterranean. Sci Total Environ 103:4756

Nachev M, Sures B (2009) The endohelminth fauna of barbel (Barbus barbus) correlates with water quality of the Danube River in Bulgaria. Parasitology 136:545-552

Olsson P-E, Kling P, Hogstrand C (1998) Mechanisms of heavy metal accumulation and toxicity in fish. In: Langston WJ, Bebiano MJ (eds) Metal metabolism in aquatic environments. Chapman and Hall, London

Olsvik PA, Gundersen P, Andersen RA, Zachariassen KE (2001) Metal accumulation and metallothionein in brown trout, Salmo trutta, from two 
Norwegian rivers differently contaminated with $\mathrm{Cd}, \mathrm{Cu}$ and $\mathrm{Zn}$. Comp Biochem Phys C 128:189-201

Pawlisz AV, Kent RA, Schneider UA, Jefferson C (1997) Canadian water quality guidelines for chromium. Environ Toxic Water 12:123-183

Podrug M, Raspor B (2009) Seasonal variation of the metal (Zn, Fe, Mn) and metallothionein concentrations in the liver cytosol of the European chub (Squalius cephalus L.). Environ Monit Assess 157:1-10

Podrug M, Raspor B, Erk M, Dragun Z (2009) Protein and metal concentrations in two fractions of hepatic cytosol of the European chub (Squalius cephalus L.). Chemosphere 75:843-849

Raspor B, Paić M, Erk M (2001) Analysis of metallothioneins by the modified Brdička procedure. Talanta 55:109-115

Roesijedi G (1992) Metallothioneins in metal regulation and toxicity in aquatic animals. Aquat Toxicol 22:81-114

Roméo M, Siaub Y, Sidoumou Z, Gnassia-Barelli M (1999) Heavy metal distribution in different fish species from the Mauritania coast. Sci Total Environ 232:169-175

Santschi PH, Bower P, Nyffeler UP, Azevedq A, Broecker WS (1983) Estimates of the resistance to chemical transport posed by the deep-sea boundary layer. Limnol Oceanogr 28:899-912

Siddall R, Sures B (1998) Uptake of lead by Pomphorhynchus laevis cystacanths in Gammarus pulex and immature worms in chub (Leuciscus cephalus). Parasitol Res 84:573-577

Sigg L, Xue HB (1994) Metal speciation: concepts, analysis and effects. In: Bidoglio G, Stumm W (eds) Chemistry of aquatic systems: local and global perspectives. Kluwer Academic Publishers

Sigg L, Black F, Buffle J, Cao J, Cleven R, Davison W, Galceran J, Gunkel P, Kalis E, Kistler D, Martin M, Noël S, Nur Y, Odžak N, Puy J, van Riemsdijk W, Temminghoff E, Tercier-Waeber M-L, Toepperwien S, Town RM, Unsworth E, Warnken KW, Weng L, Xue HB, Zhang H (2006) Comparison of analytical techniques for dynamic trace metal speciation in natural freshwaters. Environ Sci Technol 40:1934-1941

Sorensen EMB (1991) Metal poisoning in fish. CRC Press, BocaRaton

Sun L-T, Jeng S-S (1998) Comparative zinc concentrations in tissues of common carp and other aquatic organisms. Zool Stud 37:184-190

Sures B (2001) The use of fish parasites as bioindicators of heavy metals in aquatic ecosystems: a review. Aquat Ecol 35:245-255

Sures B (2002) Competition for minerals between Acanthocephalus lucii and its definitive host perch (Perca fluviatilis). Int J Parasitol 32:1117-1122

Sures B (2003) Accumulation of heavy metals by intestinal helminths in fish: an overview and perspective. Parasitology 126:S53-S60

Sures B (2008) Host-parasite interactions in polluted environments. J Fish Biol $73: 2133-2142$

Sures B, Siddall R (1999) Pomphorhynchus laevis: the intestinal acanthocephalan as a lead sink for its fish host, chub (Leuciscus cephalus). Exp Parasitol 93:6672 
Sures B, Siddall R, Taraschewski H (1999a) Parasites as accumulation indicators of heavy metal pollution. Parasitol Today 15:16-21

Sures B, Steiner W, Rydlo M, Taraschewski H (1999b) Concentrations of 17 elements in the zebra mussel (Dreissena polymorpha), in different tissues of perch (Perca fluviatilis), and in perch intestinal parasites (Acanthocephalus lucii) from the subalpin lake Mondsee (Austria). Environ Toxicol Chem 18:2574-2579

Terek B (2004) Comparison of river discharge measurements by conventional current meter and acoustic doppler current profiler. In: Morell M (ed) Proceedings of the Conference on water observation and information system for decision support (BALWOIS 2004), 25-29 May 2004. EC, IRD France, Ministry of environment and physical planning, Republic of Macedonia, Ohrid

Thielen F, Zimmermann S, Baska F, Taraschewski H, Sures B (2004) The intestinal parasite Pomphorhynchus laevis (Acanthocephala) from barbel as a bioindicator for metal pollution in the Danube River near Budapest, Hungary. Environ Pollut 129:421-429

Van Campenhout K, Infante HG, Adams F, Blust R (2004) Induction and binding of $\mathrm{Cd}, \mathrm{Cu}$, and $\mathrm{Zn}$ to metallothionein in carp (Cyprinus carpio) using HPLCICP-TOFMS. Toxicol Sci 80:276-287

Van Cleef KA, Kaplan LAE, Crivello JF (2000) The relationship between reproductive status and metallothionein mRNA expression in the common killifish, Fundulus heteroclitus. Environ Biol Fish 57:97-105

Vostradovsky J (1973) Freshwater fishes. The Hamlyn Publishing Group Limited, London

Werner J, Wautier K, Evans RE, Baron CL, Kidd K, Palace V (2003) Waterborne ethynylestradiol induces vitellogenin and alters metallothionein expression in lake trout (Salvelinus namaycush). Aquat Toxicol 62:321-328

Wiener JG, Giesy Jr JP (1979) Concentrations of $\mathrm{Cd}, \mathrm{Cu}, \mathrm{Mn}, \mathrm{Pb}$ and $\mathrm{Zn}$ in fishes in a highly organic softwater pond. J Fish Res Board Can 36:270-279

Zhang H, Davison W (1995) Performance characteristics of diffusion gradients in thin films for the in situ measurement of trace metals in aqueous solution. Anal Chem 67:3391-3400 